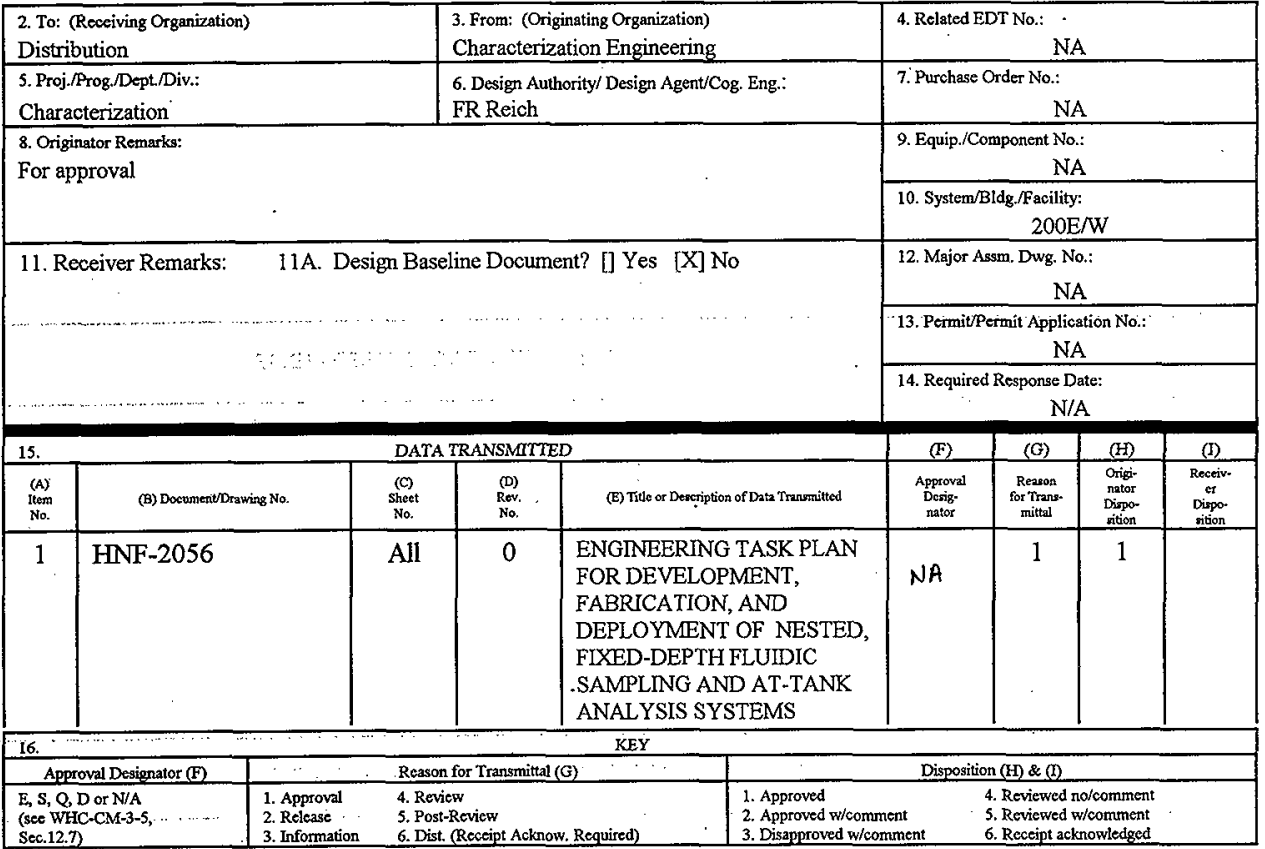

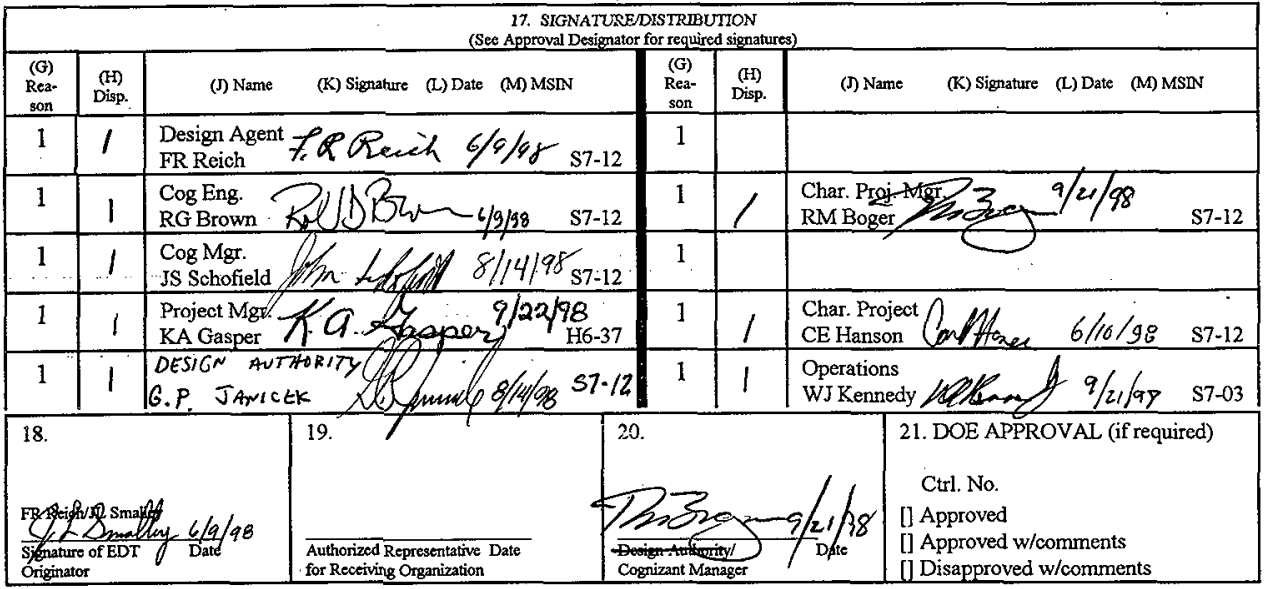


HNF-2056, REV. 0

\section{ENGINEERING TASK PLAN FOR DEVELOPMENT, FABRICATION, AND DEPLOYMENT OF NESTED, FIXED-DEPTH FLUIDIC SAMPLING AND AT-TANK ANALYSIS SYSTEMS}

\section{FR Reich}

JL Smalley

COGEMA Engineering Corporation, Richland, WA 99352

U.S. Department of Energy Contract DE-AC06-96RL13200

EDT/ECN: 622061

Org Code: 08E00

B\&R Code: EW3120074
UC: 2070

Charge Code: W7P55

Total Pages: 51

Key Words: $\quad$ waste sampling, double-shell, LAW, sampling system, at-tank analysis

Abstract: An engineering task plan was developed that presents the resources, responsibilities, and schedules for the development, test, and deployment of the nested, fixed-depth fluidic sampling and at-tank analysis system. The sampling system, deployed in the privatization contract double-shell tank feed tank, will provide waste samples for assuring the readiness of the tank for shipment to the privatization contractor for vitrification. The at-tank analysis system will provide "real-time" assessments of the sampled wastes' chemical and physical properties. These systems support the Hanford Phase 1B Privatization Contract.

TRADEMARK DISCLAIMER. Reference herein to any specific commercial product, process, or service by trade name, trademark, manufacturer, or otherwise, does not necessarily constitute or imply its endorsement, recommendation, or favoring by the United States Government or any agency thereof or its contractors or subcontractors.

Printed in the United States of America. To obtain copies of this document, contact: Document Control Services, P.O. Box 950, Mailstop H6-08, Richland WA 99352, Phone (509) 372-2420; Fax (509) 376-4989.

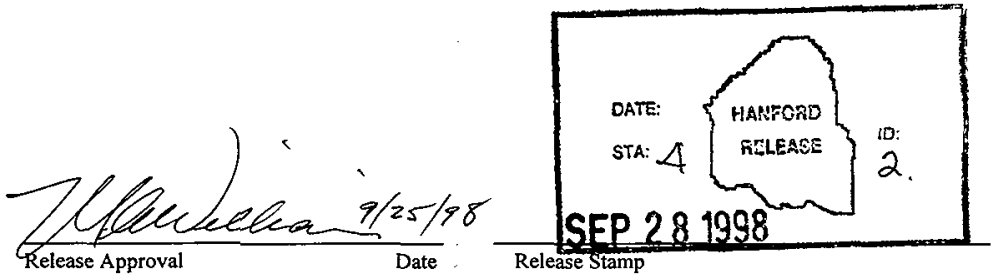

\section{Approved for Public Release}


HNF-2056, REV. 0

ENGINEERING TASK PLAN FOR DEVELOPMENT, FABRICATION, AND DEPLOYMENT OF NESTED, FIXED-DEPTH FLUIDIC

SAMPLING AND AT-TANK ANALYSIS SYSTEMS

\author{
Prepared for \\ Characterization Engineering \\ by
}

F. R. REICH

J. L. SMALLEY

COGEMA Engineering Corporation

August 1998 
HNF-2056, REV. 0 
TABLE OF CONTENTS

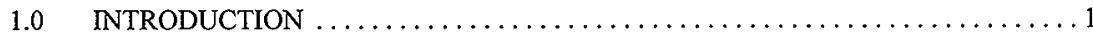

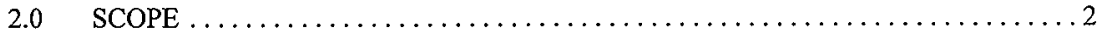

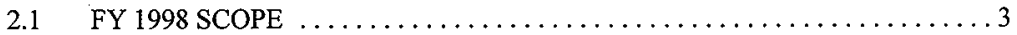

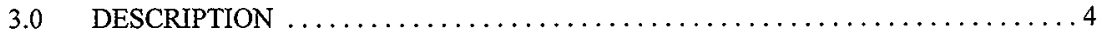

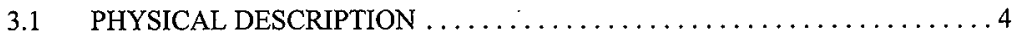

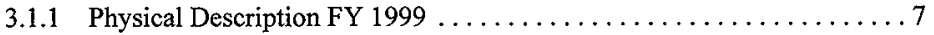

3.1.2 Physical Description FY $2000 \ldots \ldots \ldots \ldots \ldots \ldots \ldots \ldots \ldots$

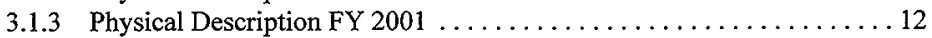

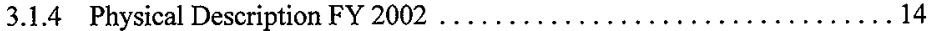

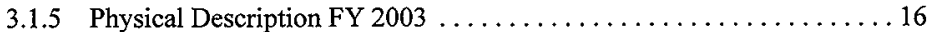

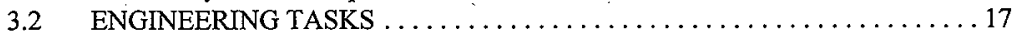

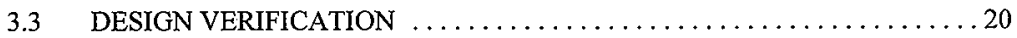

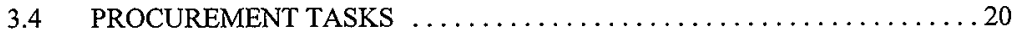

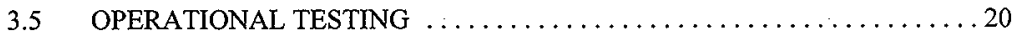

3.6 ACCEPTANCE FOR BENEFICIAL USE $\ldots \ldots \ldots \ldots \ldots \ldots \ldots \ldots \ldots \ldots \ldots \ldots \ldots$

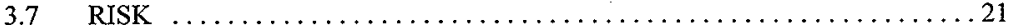

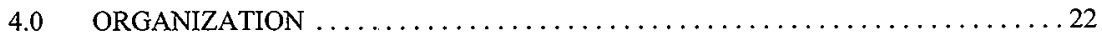

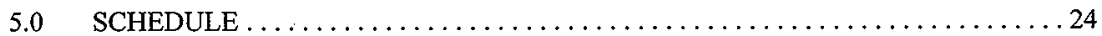

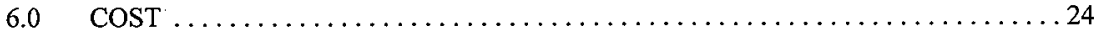

7.0 CONFIGURATION MANAGEMENT $\ldots \ldots \ldots \ldots \ldots \ldots \ldots \ldots \ldots \ldots \ldots \ldots \ldots \ldots \ldots \ldots \ldots \ldots$

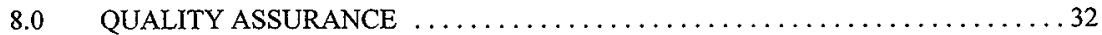

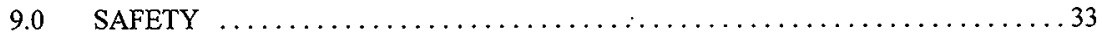

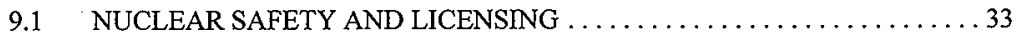

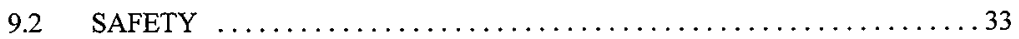

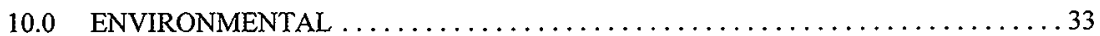




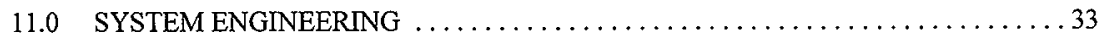

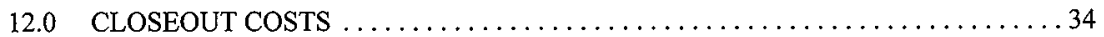

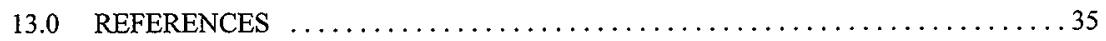

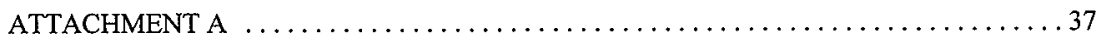

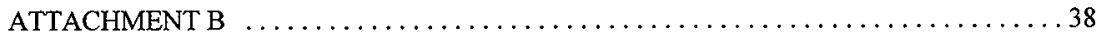

\section{TABLES}

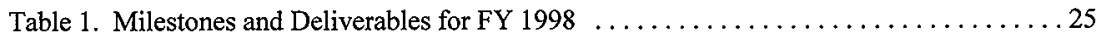

Table 2. Estimated Cost Distribution of FY 1998 Fund ..................... 26

Table 3. Estimated Costs and Proposed Funding Sources for FY 1999 .............. 27

Table 4. Estimated Costs and Proposed Funding Sources for FY $2000 \ldots \ldots \ldots \ldots \ldots \ldots 28$

Table 5. Estimated Costs and Proposed Funding Sources for FY 2001 ................ 29

Table 6. Estimated Costs and Proposed Funding Sources for FY $2002 \ldots \ldots \ldots \ldots \ldots \ldots$

Table 7. Estimated Costs and Proposed Funding Sources for FY $2003 \ldots \ldots \ldots \ldots \ldots$ 


\section{ENGINEERING TASK PLAN FOR DEVELOPMENT, FABRICATION, AND DEPLOYMENT OF NESTED, FIXED-DEPTH FLUIDIC SAMPLING AND AT-TANK ANALYSIS SYSTEMS}

\subsection{INTRODUCTION}

The final treatment of the Hanford High Level Waste (HLW) and Low Activity Waste (LAW) tank wastes will be completed through a privatization contract. The privatization contractor(s) will be responsible for waste separation/treatment and glassification, but the Hanford Site has the responsibility of supplying waste feed materials in a suitable condition and within a scheduled time interval.

The transfer of HLW and LAW waste materials will be accomplished with a transfer line between the Project Hanford Management Contract (PHMC) team staging tanks and the Privatization Contractors feed tanks. Prior to transfer to the privatization contractor, the waste feed in the PHMC team staging tank must conform to the Tank Waste Remediation System (TWRS) Privatization Contracts with BNFL, Inc. and Lockheed Martin Advanced Environmental Systems (LMAES) feed envelope A, B, and C specifications (DOE 1997a and DOE 1997b). The Privatization Phase I supernate solutions are targeted to be dilute slurry/supernate solutions with a maximum of five percent by volume solids which is expected to change to two percent solids by weight.

To assure that these waste conditions are met, the contents of the PHMC team staging tank will be sampled before the transfer to the Privatization contractors' tanks. The current approved method for sampling tank liquids is "grab" sampling. Grab sampling utilizes a "bottle on a string" technique that may be biased with materials from the upper tank elevations. In addition, grab sampling requires significant operator exposure and time for laboratory analysis. The concern associated with this method of sampling is that the long time to assure that a tank is well mixed and a representative sample has been obtained may conflict with the schedule needs for staging batches of waste feed. In order to address these concerns, the development and demonstration of a representative, rapid sampling and analysis system has been proposed. This rapid sampling and analysis system will be developed to ensure that feeds to the transfer line, and to the Privatization Contractors, can be staged successfully within tank space and schedule constraints. This system will be developed as two major tasks. The first task will be to develop and deploy a nested, fixed-depth fluidic sample retrieval system that provides waste samples that are representative of a tank's waste content. The second task will be to develop an at-tank analysis system (in-tank or at-tank deployments are options at this time) that provides on-line, real-time sample analysis data and that can be interfaced with the nested, fixed-depth fluidic sample retrieval system. 
A waste sampling system is needed that can be operated in conjunction with an active tank waste mixing system and can provide samples for analysis at the PHMC Team's 222-S Analytical Laboratory. When an at-tank sample analysis capability is available, this system would be coupled with the sample retrieval system. AEA Technology Engineering Services, Inc. (AEA) is a private firm that is currently under contract with the U.S. Department of Energy to develop fluid transfer and fluidic sampling systems for use with the radioactive waste stored in large underground storage tanks. AEA has previously developed concepts for transfer pumps and fixed elevation samplers for implementation in Savannah River Site waste tanks. Currently AEA has a contract from the Department of Energy (DOE) to design and demonstrate proof-ofprinciple of a nested, fixed-depth fluidic sample retrieval system for on-line use with Hanford's large underground radioactive waste storage tanks. This system is basically a group of fixed-depth samplers, each setup to sample waste at a specific elevation in a waste tank. The results of testing this sampling concept with Hanford waste simulants will be used to develop a nested, fixed-depth fluidic sample retrieval system for deployment in one or more Hanford double-shell tanks (DST).

This Engineering Task Plan (ETP) is the management plan document that outlines the work required to support AEA in the development of a nested, fixed-depth fluidic sample retrieval system for use in the PHMC team waste feed staging tanks and for the development of the attank sample analysis system to analyze these samples. The first task outlined by this ETP is to provide engineering consultation and complete the design for the nested, fixed-depth fluidic sample retrieval system for installation in a double-shell tank at the Hanford site. The work in this task will assure that documentation needed to meet the site's safety, operational, and readiness reviews criteria for equipment that is deployed in the Tank Farms is developed and that approvals are obtained to support installation and operational needs. The second task, which is the development of the at-tank sample analysis system, is currently a minor task for this ETP in fiscal year (FY) 1998. Primary support for this task in FY 1998 is provided by the Robotics Cross Cut Program. As this work progresses, this ETP will be modified to integrate detailed budgets and schedules that will be supported by EM-30 and EM-50 sources. These modifications will include development, testing, and deployment activities.

\subsection{SCOPE}

This ETP provides for the technical management support for the development and deployment of the nested, fixed-depth fluidic sample retrieval and on-line, real-time analysis systems. This includes the identification of activities needed to support the development, testing, verification, and validation of these systems in order to meet criteria needed for in-tank (or at-tank) deployment. This also includes the identification of resources to complete these activities and the development of schedules and budgets for these activities. 
HNF-2056, REV. 0

The scope of these tasks includes the following:

technical interfacing and reviews with AEA in their development of the nested, fixed-depth fluidic sample retrieval system and other resources to be identified for the development of the tank interface system and the real-time, on-line sample analysis system

engineering and design support for cold testing systems at Hanford with simulated waste materials

preparation of functional/design requirements and other necessary technical baseline documentation for the nested, fixed-depth fluidic sample retrieval and at-tank sample analysis systems

design of the interface hardware and controls to support the nested, fixed-depth fluidic sample retrieval and at-tank sample analysis systems that will allow safe, low exposure installation, maintenance, and operation of these systems in the PHMC team feed tank

development of operational, safety, environmental, and maintenance documentation and the completion of Readiness Reviews required prior to installation of the nested, fixed-depth fluidic sample retrieval and at-tank sample analysis systems in a DST

identification of tank farm interfaces, resources, and scheduling, and management of those resources to complete cold testing and hot deployment of the nested, fixed-depth fluidic sample retrieval and at-tank sample analysis systems.

\section{$2.1 \quad$ FY 1998 SCOPE}

The FY 1998 work scope covers the activities and funding for FY 1998. This includes engineering consulting and design support to AEA to ensure that the nested, fixed-depth fluidic sample retrieval system can be deployed in a Hanford feed staging tank and provide representative waste samples with Hanford's candidates for LAW Feed (Envelopes A, B, and C) within a time frame needed to support the privatization contract. This task will provide technical assistance and the operational, safety, and readiness review documentation that is required for tank farm deployment of hardware.

The FY 1998 scope of this task includes the following:

technical integration management of this ETP activity, development and approval of a deployment strategy and implementation plan for the nested, fixed-depth fluidic sample retrieval and analysis system and obtaining the necessary approvals for implementation, technical interfacing and design reviews with AEA in their development of the 
HNF-2056, REV. 0

nested, fixed-depth fluidic sample retrieval system and with other PHMC and Site contractors supporting this activity,

development of informal, periodic reports to meet EM-30 and EM-50 program

requirements,

the development of a preliminary Level 2 Component Specification (Functional

Design Criteria) document for the nested, fixed-depth fluidic sample retrieval

system that includes preliminary requirements for the at-tank sample analysis

system,

development of a test plan for $\mathrm{AEA}$, containing the necessary test requirements

that demonstrate the performance of the nested, fixed-depth fluidic sample retrieval system to meet the criteria in the Level 2 Component Specification. conceptual design for the tank interface to support deployment of the nested, fixed-depth fluidic sample retrieval and at-tank analysis systems in a DST.

\subsection{DESCRIPTION}

\subsection{PHYSICAL DESCRIPTION}

This is a multi-year, multi-task effort. At completion of all tasks, nested, fixed-depth fluidic sampling systems with integrated at-tank analysis systems will be deployed in DSTs in support of the Hanford LAW and HLW privatization activity.

The first task will be to develop the nested, fixed-depth fluidic sampling system for deployment in the PHMC feed tank where it will provide representative tank waste samples for validation of waste properties prior to the waste transfer to the privatization contractor. This system will be cold and hot tested at Hanford to validate and verify its performance prior to use in the PHMC feed tank.

The second task will be to develop an at-tank waste analysis system that will interface with the waste effluent stream from the nested, fixed-depth fluidic sampling system. This system will analyze physical and chemical properties that can be used to assess the homogeneity of the waste in the feed tank and the tank's readiness status for transfer to the privatization contractor.

This ETP breaks the work down into specific deliverables and responsibilities for the current FY and generalizes planning for out years to meet the final objective of a system that is useful for supporting the privatization contract. This plan will be updated with detailed planning for subsequent years as this project progresses, and funding is made available by EM-30 and EM-50 programs. 
The specific objective for FY 1998 is to develop and demonstrate a nested, fixed-depth fluidic sample retrieval system that is capable of taking representative samples of waste at fixed-depths in a waste feed/mixing tank. This work will be done with tank waste simulants and with nested, fixed-depth fluidic sample retrieval components in mockups representative of anticipated DST configurations. To support the completion of this objective, a Level 2 Component Specification (Functional Design Criteria) will be developed along with test plans, acceptance criteria, and conceptual interface design. The activities for FY 1998 are based on the work scope and funding provided by the DOE Office of Science and Technology (EM-50) Tanks Focus Area (TFA) program through Technical Task Proposal (TTP) RL08-WT22, "PHMC Characterization and Safety - Nested, Fixed-depth Fluidic Sampling and Analysis System."

A deployment strategy and plan will be developed as the basis for FY 1999 and outyear planning. This document will identify task funding and provisions to transition from EM-50 to the DOE's Environmental Management (EM-30) TWRS funding. It is assumed that this document will be revised each program year. The necessary approvals will be obtained for input into the FY 1999 TWRS Multi-Year Program Plan (MYPP) to cover the EM-30 funding. As part of this task, the planning effort to support additional EM-50 funding requests will be completed.

The Pacific Northwest National Laboratory (PNNL) will develop test simulant recipes to support AEA's testing of the nested, fixed-depth fluidic sampling system concepts and prototypes. The chemical recipes will include a set chemical analytes, radionuclides, and physical parameters to support the development of analysis functions and design criteria. These recipes will also be used to support the selection and validation of instrumentation for the at-tank analysis system. The Lockheed Martin Hanford Corporation (LMHC) Tank Characterization group will provide technical review and support in identifying the physical and chemical properties and their ranges for these simulants. The simulant recipes will be based on known Phase I Privatization Contract information as well as existing tank waste characterization data and will be representative of the range of wastes for Privatization Contract envelopes A, B, and C. The physical simulants will be based on non-hazardous materials that adequately bound the expected Hanford tank waste properties to be encountered and that can be disposed of easily. The recipes will be provided to the PHMC Team for review and comment prior to acceptance for use.

Level 1 and Level 2 Component Specifications are the current method used to provide the requirements to which TWRS systems, structures, and components will be designed. The Level 2 Component Specification document replaces and expands the information that would have been in a Functional Design Criteria document. For the Level 1 and 2 Specification functions and requirements, analyses are conducted to provide a hierarchy of functions and requirements that supports the development of a traceable and defensible top-down system architecture. The Level 2 Component Specification expands the level of detail provided by the Level 1 Specification with a focus on defining sub-systems and components within a system. Because of the lack of site experience in the generation of these documents, there is a level of 
HNF-2056, REV. 0

uncertainty for the cost and time to develop the Level 2 Component Specification document. The estimated cost and time for this FY 1998 activity is based on the generation of a typical draft for a Functional Design Criteria document that may not be sufficient to complete a Level 2 Component Specification document; the schedule may not allow for major iterations to resolve issues in the guidance for generating a final Level 2 Component Specification document. For FY 1998 COGEMA Engineering Corporation (COGEMA) (formerly SGN Eurisys Services Corporation [SESC]) will develop the Level 2 Component Specification document data/sections that are needed to support the completion of hardware design, design reviews, and proof-ofprinciple testing of the nested, fixed-depth fluidic sampling system and to complete review of concepts identified for at-tank waste analysis. This draft document will provide the physical and chemical property range of the waste materials that must be sampled. This specification will also contain environmental and physical criteria for hardware operating inside the tank farm, criteria for in-tank operation and criteria for using site approved casks to transport samples to the $222 \mathrm{~S}$ Laboratory. This will allow the nested, fixed-depth fluidic sample retrieval system to be deployed to provide waste samples for analysis in the $222 \mathrm{~S}$ laboratory. The development and integration of the at-tank sample analysis system will be completed at a later date. The Level 2 Component Specification will be developed per WHC-IP-0842 and will be based on the Data Quality Objectives (DQOs) for LAW feed, or anticipated revisions of the DQO based on the DOE's negotiations with the privatization contractors, as well as the current Tank Farms Authorization Basis $(\mathrm{AB})$ and applicable state and federal regulations.

A test plan containing the necessary test requirements to demonstrate the performance of the nested, fixed-depth fluidic sample retrieval system to meet the criteria in the Level 2 Component Specification will be written and approved. This test plan will include the specific simulant mixtures to be tested and criteria for verification and validation of the nested, fixed-depth fluidic sampling system. The test plan will also contain a test matrix that indicates which requirement is being demonstrated and the acceptance criteria for each test. This test plan will provide the basis for the proof-of-principle testing that will be completed at AEA. Prior to completion of the proof-of-principle testing, an informal review of the AEA nested, fixed-depth fluidic sampling system design will be completed. An informal test report will be written, summarizing the results of the tests performed, conclusions, and lessons learned. The test report will also include the results of the informal design review of the tested equipment.

A conceptual design report for the tank interface equipment needed to deploy the nested, fixed-depth fluidic sampling system at a DST will be prepared. The report will identify the necessary tank farm interfaces as well as the proposed cask and sample transport systems required to ship the sample to a laboratory for analysis.

A technical review will be conducted on AEA's nested, fixed-depth fluidic sampling system prior to their completion of the prototype system design. The design review committee will consist of representatives from quality, safety, environmental, and operations. The committee 
will review the pertinent design documentation against the Level 2 Component Specification criteria. A review of the analysis concepts identified by PNNL for the at-tank analysis system will also be completed.

\subsubsection{Physical Description FY 1999}

The activities and scope for FY 1999 are dependent on the availability of funding and the results of the FY 1998 proof-of-principle testing with the nested, fixed-depth fluidic sampling system concepts. In FY 1999 the development of the nested, fixed-depth fluidic sampling and at-tank analysis systems will be completed. A nested, fixed-depth sampling system and hardware for interfacing to a waste tank will be developed and fabricated. The Level 2 Component Specification document will be completed, reviewed, and issued. Documentation will be prepared to support the safe deployment of the systems in a DST. A hazards assessment will be completed to identify any issues related to safety and to the Site's AB. The location for cold testing the sampling system will be identified and work to prepare the site for cold testing initiated. The objective is to have the site ready to receive equipment in FY 2000. Selected analytical instruments and measurement concepts will be demonstrated and proof-of-principle tests completed with simulants to identify measurement accuracy, sensitivity and precision. The functions and requirements for the nested, fixed-depth fluidic sampling system and the at-tank analysis system will be updated based on design and test data.

The FY 1999 activities include the following:

Level 2 Component Specification (Functional Design Criteria):

Level 2 Component Specification Revision:

The Level 2 Component Specification for the nested, fixed-depth sampling and attank analysis systems will be finalized, incorporating lessons-learned data from design reviews, testing and preliminary hazards assessment for the sampling system and conceptual design and proof-of-principle testing of the analysis concepts.

Nested, Fixed-depth Fluidic Sampling System Design/Fabrication/Acceptance:

The design and the fabrication of the nested, fixed-depth fluidic sampling system will be completed. This will be a two-step design process where an initial conceptual design is first completed, followed by a formal design. A final design review will be completed prior to initiating fabrication. Acceptance of the hardware is an early FY 2000 activity.

Tank Interface System Hardware:

The design and fabrication of the hardware needed to interface the nested, fixed-depth fluidic sampling system with a DST will be completed. This will be a 
two-step design process where an initial conceptual design is first completed, followed by a formal design. A final design review will be completed prior to initiating fabrication. Acceptance of the hardware is an early FY 2000 activity.

Nested, Fixed-depth Fluidic Sampling System Cold Testing - Hanford:

Identify and Prepare Cold Test Site:

In this task a Hanford site facility will be identified where the cold testing can be completed with the nested, fixed-depth fluidic sampling system hardware.

Preparations and modifications will be initiated that are needed to accommodate the installation of the nested, fixed-depth sampling system hardware which will be completed in FY 2000.

In-tank Deployment Documentation:

Hazards Assessment:

An initial hazards assessment will be completed on the nested, fixed-depth sampling systems design. This assessment will be used in FY 2000 to develop documentation needed by the site for the installation and operation of hardware in a tank farm (safety equipment list, environmental permits, etc.).

At-tank Analysis System Concept Development and Testing:

Complete concept development and proof-of-principle testing of the at-tank analysis system concepts. Selected analytical instruments and measurement concepts will be tested, demonstrated, and tests completed to identify measurement accuracy, sensitivity and precision. These tests will use simulants that are representative of the waste constituents expected to be found in waste envelopes A, B, and C. Update the Level 2 Component Specification for the attank analysis system.

At-tank Analysis System Detailed Design, Fabrication, and Hardware Acceptance:

Definitive Design:

Complete the detailed design of the at-tank analysis system and initiate procurement of a system capable of handling tank waste materials. Procurement is an early FY 2000 activity.

Project Planning:

Engineering Task Plan:

Revise the Engineering Task Plan. The ETP provides detailed costs and 
HNF-2056, REV. 0

schedules for current year activities and functions as a Memorandum of Understanding with EM-30. Document revisions will be needed, based on the status of the activities and the results of design and test activities.

Deployment Strategy and Plan:

Revise the Deployment Strategy and Plan Document. The deployment strategy and plan identifies schedules and the sources of funding for outyear activities. Document revisions will be needed, based upon the status of funds and funding sources and on the progress with the technical design and test activities.

Program Management:

This task provides the technical integration and oversight to coordinate the technical development work performed by the PHMC site team. This work is supported by the TFA and the Robotics Cross Cut Program, DOE work contracted with AEA, and the work scope to be completed by the PHMC Team from LMHC, PNNL, Numatec Hanford Corporation (NHC), and COGEMA. This task also includes the preparation of reports to support monthly and special reporting needs.

\subsubsection{Physical Description FY 2000}

The activities and scope for FY 2000 are dependent upon the availability of funding and the results of testing of the nested, fixed-depth fluidic sampling system and the real-time, on-line sample analysis system. Assuming that funding is available, the objectives for FY 2000 are to complete acceptance checkout of the prototype nested, fixed-depth fluidic sampling system hardware, install the hardware in the cold test facility and complete cold testing, complete formal acceptance and operational testing, prepare documentation needed to deploy hardware in a DST, and develop a hot installation and test plan. The lessons learned during acceptance testing will be incorporated into the nested, fixed-depth fluidic sampling system design and the hardware modified accordingly. For the at-tank analysis system the objectives include the design and fabrication of the system, hardware acceptance checkout, and identification and preliminary preparations of a cold test site. The schedule of the FY 2000 activities will be updated, based on the FY 1999 strategy and deployment plan. The Deployment Strategy and Plan will identify the activities/areas that are to be covered with each source of funds. 
The FY 2000 activities include the following:

Project Planning:

Engineering Task Plan:

Revise the Engineering Task Plan. Revise as needed, based upon the status of the activities and the results of design and test activities.

Deployment Strategy and Plan:

Revise the Deployment Strategy and Plan Document. Revise based on the status of funds and funding sources and on the progress with the technical design and test activities.

Nested, Fixed-depth Fluidic Sampling System Design, Fabrication and Acceptance: Hardware Acceptance and Checkout:

Complete the checkout and acceptance of the nested, fixed-depth fluidic sampling system hardware. Checkoff lists will be prepared and hardware examined to ensure that hardware conforms with design parameters.

Tank Interface System Hardware:

Hardware Acceptance and Checkout

Complete the checkout and acceptance of the tank interface hardware. Checkoff lists will be prepared and hardware examined to ensure that hardware conforms with design parameters.

Nested, Fixed-depth Fluidic Sampling System Cold Testing - Hanford:

The final preparations will be completed on the cold test facility, and then the nested, fixed-depth sampling system hardware will be installed in the facility. Hardware checkout and acceptance testing will be complete as the nested, fixed-depth sampling system hardware and the tank interface hardware is received and set up. Functional (cold) testing will be completed using a matrix of waste simulants that cover the expected range of material characteristics for waste A, B, and $C$ envelopes. Issues related to the handling, storage, and disposal of simulants will also be addressed. The lessons learned from the checkout of the nested, fixed-depth sampling system hardware and the results of the Functional testing will be incorporated into the nested, fixed-depth sampling system design. Modifications will then be made to the hardware where deemed necessary to meet performance criteria identified in the Level 2 Component Specification document.

Nested, Fixed-depth Fluidic Sampling System Acceptance Testing:

Acceptance Testing following draft Tank Operations Procedures will be completed with the nested, fixed-depth sampling system. An Acceptance Test 
Plan (ATP) will be developed and site approvals obtained for the plan.

Acceptance testing will then be completed in the cold test facility using the matrix of tank waste simulants and test procedures identified in the ATP. Completion of the testing will provide the verification and validation data for the performance of the nested, fixed-depth sampling system. Successful completion of these tests means that the system is ready for hot installation and will perform as designed to support the Privatization Contract needs.

Nested, Fixed-depth Fluidic Sampling System Operational Testing and Training: An Operational Test Plan (OTP) will be developed and site approvals for the plan following Tank Operations guidance. Site operators will be trained in the installation and operation of the nested, fixed-depth sampling system and the tank interface hardware. Operational testing will be completed with the nested, fixed-depth fluidic sampling system to verify and validate operating procedures. The OTP results will be documented and formally released.

Nested, Fixed-depth Fluidic Sampling System In-Tank Deployment Documentation: Documentation required by Tank Operations for the deployment of hardware in the tank farms will be developed, reviewed, and approved in this task. A Safety Equipment List will be developed that addresses safety issues, such as flammable gas, organics, and prevention of the spread of contamination. The need for environmental permitting will be assessed and documentation prepared to obtain permits as required. The $A B$ for tank farm operation will be reviewed and updated as required to include sampling with the nested, fixed-depth sampling system.

Nested, Fixed-depth Fluidic Sampling System In-Tank Hot Installation:

Hot Installation Plan and Schedule:

In this task a plan for the installation of the nested, fixed-depth sampling hardware in a DST will be developed, with Tank Farm Operations approvals. The plan will identify resources, schedules, special equipment (e.g., cranes) that will be needed to install the nested, fixed-depth fluidic sampling hardware.

Readiness Assessment - In-Tank Installation/Operation:

Nested, Fixed-depth Fluidic Sampling System Readiness Assessment:

In FY 2000, the process to complete a PHMC Readiness Assessment (RA) will be initiated. The requirements for the review will be developed, following Tank Operations procedures and a plan to complete the review process developed. In FY 2001 the RA will be complete prior to in-tank installation of the nested, fixed-depth fluidic sampling system and tank interface hardware. 
At-Tank Analysis System Design, Fabrication, Hardware Acceptance:

The procurement and fabrication of an at-tank analysis system will be completed in this task. Acceptance checkout and testing completed when the fabrication is completed. A formal design review will be completed prior to initiating fabrication. Checkout lists will be prepared and equipment examined to ensure conformation with design parameters and specifications.

At-tank Analysis System Cold Testing - Hanford:

A location at the Hanford site will be identified where cold tests can be completed with the at-tank analysis system. The site selection issues include the handling, storage, and disposal of simulants, since these simulants will be made up of representative, non-radioactive waste chemical species. Facility preparations will be completed and then the at-tank analysis system hardware will be installed. Hardware checkout and acceptance testing will proceed as the hardware is set up. Functional and performance testing will be completed. Cold testing will be completed using a matrix of waste simulants that cover the expected range of material characteristics for waste $\mathrm{A}, \mathrm{B}$, and $\mathrm{C}$ envelopes. The lessons learned from the checkout of the at-tank analysis system hardware and the results of the cold testing will be incorporated into design revisions for the systems design. Modifications will then be made to the hardware where deemed necessary to meet performance criteria identified in the Level 2 Component Specification document.

\section{Program Management:}

This task provides the technical integration and oversight to coordinate the technical development work. This task also includes the preparation of reports to support monthly and special reporting needs.

\subsubsection{Physical Description FY 2001}

The activities and scope for FY 2001 are dependent on the availability of funding and the results of testing the real-time, on-line sample analysis system. Assuming that funding is available, the objectives for FY 2001 are to install the nested, fixed-depth fluidic sampling system in a DST and complete hot testing and a hot demonstration. Readiness reviews and functional checkouts will be completed to ensure that the system is ready for continued operation. For the at-tank analysis system, a cold test site will be prepared and the system installed and cold testing completed. Operational Testing and Acceptance Testing will be completed following Tank Operations procedures. Lessons learned from checkout and testing will be used to modify the hardware where deemed necessary to meet the criteria in the Level 2 Component Specification for the at-tank analysis system. 
The activities for FY 2001 include the following:

Project Planning:

Engineering Task Plan:

Revise the Engineering Task Plan, updating task schedule and cost data.

Deployment Strategy and Plan:

Revise the Deployment Strategy and Plan Document based upon the status of funds and funding sources and on the progress with the technical design and test activities.

Readiness Assessment - In-tank Installation and Operation:

Complete a PHMC RA before the deployment and installation of the nested, fixed-depth sampling system in a DST. The review process will follow the Tank Operations procedures.

Nested Fixed-depth Fluidic Sampling System In-Tank Hot Installation and Operation: The installation of the nested, fixed-depth fluidic sampling system hardware in a DST will be completed, following the plan that was developed in FY 2000. A functional checkout will be completed as the system modules are installed and a functional checkout completed on the whole system when installation is completed.

Nested, Fixed-depth Fluidic Sampling System Hot Testing and Demonstration: A hot test plan will be prepared and hot testing completed with the nested, fixed-depth fluidic sampling system. The testing will include functional as well as limited validation and verification tests to assure that the sampling system is extracting representative wastes from the tank. The plan will be reviewed and approvals obtained from PHMC Privatization Contract support and from Tank Operations. At the completion of testing, a hot demonstration of the nested, fixed-depth fluidic sampling system will be completed.

Readiness Checklist for Continued Operation - Nested, Fixed-depth Fluidic Sampling System:

A readiness checklist will be developed and completed based upon the test performance of the nested, fixed-depth fluidic sampling system. The results of the checklist will be the basis for continued operation of the sampling system to support Privatization Contract waste sampling needs. 
At-tank Analysis System Acceptance Testing:

Prepare, review and approve ATP:

ATP will be developed and site approvals obtained for the plan. The testing to comply with the ATP will be completed early in FY 2002 in the cold test facility using the matrix of tank waste simulants and test procedures identified in the ATP.

At-tank Analysis System Operational Testing and Operator Training:

Prepare, review and approve OTP:

An OTP will be developed and site approvals obtained for the plan following Tank Operations procedures. The testing and operator training will be completed in early FY 2002.

At-tank Analysis System Deployment Documentation

Documentation required by Tank Operations for the deployment of hardware in the tank farms will be developed, reviewed, and approved in this task. A hazards assessment will be completed on the design and hardware of the at-tank analysis system. This assessment will be used to define documentation needs for the installation and operation of hardware in a tank farm. A Safety Equipment List will be developed that addresses safety issues such as flammable gas, organics, and prevention of the spread of contamination. The need for environmental permitting will be assessed and documentation prepared to obtain permits as required. The $\mathrm{AB}$ for tank farm operation will be reviewed and updated as required to include the operation of the at-tank analysis system.

Program Management:

This task provides the technical integration and oversight to coordinate the technical development work. This task also includes the preparation of reports to support periodic and special reporting needs.

\subsubsection{Physical Description FY 2002}

The activities and scope for FY 2002 are dependent upon the availability of funding and the results of testing the real-time, on-line sample analysis system. In FY 2002 the at-tank analysis system will be installed in the DST containing the nested, fixed-depth sampling system. A hot installation plan will be developed to coordinate resources needed during the installation process. After installation is complete and an initial system checkout is complete, hot testing and a system demonstration will be completed. A readiness checklist will then be completed to before system operation is continued to support the Privatization Contract needs. 
The activities for FY 2002 include the following:

Project Planning:

Engineering Task Plan

Revise the ETP.

Deployment Strategy and Plan:

Revise the Deployment Strategy and Plan Document.

Integrate with At-tank Analysis System:

The work to integrate the nested, fixed-depth fluidic sampling system with the attank analysis system will be completed in this task. Some modifications to the nested, fixed-depth sampling system may be necessary to convert it from a standalone sample acquisition to an integrated sampling and analysis system. This task will be completed in parallel with the at-tank analysis system hot installation task.

At-tank Analysis System Acceptance Testing:

The Acceptance Testing will then be completed in the cold test facility using the matrix of tank waste simulants and test procedures identified in the ATP.

Completion of the ATP will provide the verification and validation data for the performance of the at-tank analysis system. Successful completion of these tests means that the system is ready for hot installation and will perform as designed to support the Privatization Contract needs.

At-tank Analysis System Operational Testing and Operator Training:

Site operators will be trained in the installation and operation of the at-tank analysis system. Operational testing will then be completed to verify and validate operating procedures. The OTP results will be documented and formally released.

Readiness Assessment - At-tank Installation

Complete a PHMC RA prior to the deployment and installation of the at-tank sample analysis system. The assessments will initiated after operational OTP and acceptance testing have been successfully completed. The review process will follow the Tank Operations procedures.

At-tank Analysis System Hot Installation:

In this task, the at-tank analysis system will be installed at a DST where the nested, fixed-depth sampling system is installed. A plan will be developed and approvals obtained from Tank Farms Operations group prior to initiating installation. The plan will identify resources, schedules, special equipment, etc., 
HNF-2056, REV. 0

that will be needed for installation. After installation, a functional checkout will be completed as the system modules are installed and a functional checkout completed when the installation is completed.

At-tank Analysis System Hot Testing and Demonstration:

Hot test plan and initiation of testing:

A hot test plan will be prepared and hot testing completed for the at-tank analysis system. The plan will be reviewed and approvals obtained from PHMC

Privatization Contract support and from Tank Operations. The testing will include functional as well as limited validation and verification tests to ensure that the system is indicating the waste analytes and physical properties correctly. Hot testing will then be initiated, and a demonstration of the at-tank analysis system with the nested, fixed-depth fluidic sampling system may be completed, based on the results of the hot testing.

\section{Program Management:}

This task provides the technical integration and oversight to coordinate the technical development work. This task also includes the preparation of reports monthly and special reporting needs.

\subsubsection{Physical Description FY 2003}

The activities and scope for FY 2003 are dependent upon the availability of funding and the results of testing the real-time, on-line sample analysis system. In FY 2003, the hot testing of the at-tank analysis system will be completed and a hot demonstration completed. A readiness checklist will then be completed before system operation is continued to support the Privatization Contract needs.

The activities for FY 2003 include the following:

At-tank Analysis System Hot Testing and Demonstration:

Completion of hot testing and hot demonstration:

Hot testing of the at-tank analysis system with the nested, fixed-depth fluidic sampling system will be completed. A hot demonstration will then be completed. The testing and demonstration will provide data that indicates the ability of the system to provide representative tank waste screening/characterization data in a timely and economical manner.

Readiness Checklist for Continued Operation:

A readiness checklist will be developed and completed based upon the test performance of the integrated at-tank analysis and nested, fixed-depth sampling 
systems. This checklist will be the basis for continued operation of the system to support Privatization Contract waste sampling needs.

Program Management:

This task provides the technical integration and oversight to coordinate the technical development work. This task also includes the preparation of reports monthly and special reporting needs.

\subsection{ENGINEERING TASKS}

The specific engineering tasks to be completed for FY 1998 are shown below. In addition to the specific engineering tasks, this list indicates the responsible organizations expected to complete each task. This list will be updated with specific engineering activities for completion of this project when the detailed planning for those out years is complete. All documentation provided as deliverables in accordance with this ETP shall be in both hard copy and electronic copy.

Program Management: COGEMA Engineering Corporation (COGEMA Engineering) will provide the technical project management for the PHMC team developing the nested, fixed-depth fluidic sampling system. COGEMA Engineering will provide project oversight of Lockheed Martin Hanford Corporation (LMHC), AEA, and others to ensure that all of the technical requirements for successful deployment are completed. LMHC will provide the design authority, who has the ultimate responsibility for the technical adequacy of the equipment at completion of this project per HNF 1997a. COGEMA Engineering will work closely with the LMHC program management and design authority to resolve any issues as they arise and to communicate technical and schedule progress. COGEMA will develop the Technical Task Plan (TTP), for submittal to EM-50 TFA, for all FY 1998 PHMC, COGEMA, and PNNL activities and commitments associated with this ETP. COGEMA shall also work with LMHC to develop the planning documentation to support the LMHC effort to obtain other EM-50 funding. LMHC will make the changes to the appropriate sections of the FY 1999 MYPP so that TWRS (EM-30) funding can be obtained.

Project Planning: Deployment Strategy and Plan: LMHC will provide the lead in the development of the Deployment Strategy and Plan for the nested, fixed-depth fluidic sampling system. This plan will identify EM-50 and TWRS (EM-30) work scope and funding allocations. The document will identify a path to transition from EM-50 to TWRS (EM-30) funding sources. COGEMA Engineering shall assist LMHC in the drafting of the plan and in obtaining reviews and approvals. 
Project Planning - ETP): COGEMA Engineering will develop and obtain reviews to issue an ETP (Boger 1997) (this document). The ETP will be released detailing the roles and responsibilities for completion of activities for this FY. COGEMA Engineering will then revise the ETP to include detailed planning for completion of the project in follow-on years. The ETP will also be revised in FY 1999 and other out years to reflect status, funding, and team relationships. The ETP will be issued as a PHMC team document per HNF 1997b and HNF 1997c, with subsequent revisions per HNF 1997d.

Test Simulant Development: PNNL, with support of representatives from LMHC, will determine the expected waste types to be sampled and the range of their chemical and physical properties. From this information PNNL will specify the test simulants to be tested. In addition to the test simulant determination, PNNL will determine the set of chemical analytes, radionuclides, and physical parameters needed to be analyzed by the on-line, real-time sample analysis system. This information will be used by PNNL robotic program to assist in preliminary instrumentation identification and functional requirements. The results of these two studies shall be documented in a specification. This specification will be reviewed by representatives from LMHC prior to release and then issued as a PHMC team document per HNF 1997b and HNF 1997c.

Level 2 Component Specification: For FY 1998 COGEMA Engineering will develop the Level 2 Component Specification document data/sections that are needed to support the completion of hardware design, design reviews, and proofof-principle testing of the nested, fixed-depth fluidic sampling system and to complete review of concepts identified for at-tank waste analysis. The Level 2 Component Specification document replaces and expands the information that was formerly in the Functional Design Criteria document. Because of the lack of site experience in the generation of these documents, there is a level of uncertainty for the cost and time to develop the Level 2 Component Specification document. Development of the Level 2 Component Specification will be an iterative process requiring the participation of representatives from the entire PHMC team, including PNNL and AEA. In addition to supporting development, the team members will provide technical reviews with documented comments. The draft Level 2 Component Specification sections will provide the physical and chemical property ranges of the waste materials that must be sampled and will also contain environmental and physical criteria for hardware operating inside the tank farm, criteria for in-tank operation, and requirements and criteria for using site approved casks to transport samples to the 222S Laboratory and to the Privatization Contractors Laboratories. This will allow the nested, fixed-depth fluidic sample 
retrieval system to be deployed to provide waste samples for analysis in the 222S Laboratory. The development and integration of the at-tank sample analysis system will be completed at a later date. Approval by representatives from LMHC will be required before issuance and use of the draft Level 2 Component Specifications. The Level 2 Component Specification will be completed in FY 1999 and will be revised as necessary to accommodate emerging issues. The Level 2 Component Specification will be developed per WHC-IP-0842 and will be based on the DQOs for LAW feed, or anticipated revisions of the DQO based on the DOE's negotiations with the privatization contractors, as well as the current tank farms $\mathrm{AB}$ and applicable state and federal regulations.

Design Review: Under the leadership of LMHC, the PHMC team will perform an interim, informal design review of the variable depth sample retrieval system and of the Level 2 Component Specifications and concepts identified by PNNL for at-tank analysis of waste chemical and physical properties (task supported by the Robotics Cross Cut Program, TTP RL37C131). Review team members will be selected from engineering, quality, safety, and operations staff within the Tank Engineering and Operations Group. This review will be informal in nature, and a letter report will be issued summarizing the findings. This design report will not contain a design for a transport cask, as it is a basic premise that an existing transport cask will be available for use in this application.

Test Plan: COGEMA Engineering will develop a test plan per HNF $1997 \mathrm{f}$. Development of this test plan will require participation by representatives from LMHC, PNNL, and AEA. In addition to supporting development of the test plan, team members will provide technical reviews with documented comments. The test plan will be issued as a PHMC team document per HNF 1997b and HNF 1997c. LMHC, PNNL, and COGEMA Engineering will be responsible for developing the test matrix to be incorporated into the test plan. The test matrix will indicate which requirement is being demonstrated and the acceptance criteria for each test. The test plan will require approval by representatives from LMHC prior to issuance.

Hardware Development: COGEMA Engineering and LMHC will oversee AEA in the development of the hardware for the variable depth sample retrieval system. AEA will design, fabricate, and test the prototype hardware, based on the retrieval concept (DOE PTP, Contract Number TFA/PF/17/v1). COGEMA Engineering and PHMC team members will review the AEA system design and will witness proof-of-principle testing and a demonstration of the nested, fixed-depth sampling system at AEA. AEA will write a test report with the results of their design and test activities. The test report will contain the raw data for each test 
run, the results of the testing, conclusions, and lessons learned. COGEMA Engineeringwill be responsible for the development of a conceptual design report for the tank interface equipment that will allow the nested, fixed-depth sampling system to be deployed in a waste staging tank. This effort will require participation by representatives from LMHC and PNNL. COGEMA Engineering and $\mathrm{LMHC}$ will issue a letter report summarizing the results of the review of the nested, fixed-depth fluidic sampling hardware at AEA and the results of the observed proof-of-principle testing. The test report will be approved by LMHC before issuance.

\subsection{DESIGN VERIFICATION}

This task is being performed using the development control process for development of prototype systems (HNF 1997g). A determination was not made before the release of this ETP as to whether or not the initial equipment fabricated to demonstrate proof-of-principle testing will have facility use potential, however, to maintain facility use potential, a design verification will be performed for the design media produced by AEA. The design verification method will be formal design review (HNF 1997h). The design review chairman will be the LMHC characterization project Design Authority. The design review committee will consist of representatives from quality, safety, environmental, operations, and other technical consultants as deemed necessary by the design review chairman. The committee will review the pertinent design documentation developed by AEA and test results against the functional design criteria and release a design review report detailing the acceptance of the design for future facility use potential.

\subsection{PROCUREMENT TASKS}

All procurement activities required for this task will be handled by LMHC. The safety classification of the components will be determined by the LMHC design authority with input from COGEMA Engineering personnel. Any Commercial Grade Item (CGI) dedication forms, for safety class or safety significant equipment, required to support procurement activities will be prepared by COGEMA Engineering personnel in accordance with WHC $1996 \mathrm{a}$.

\subsection{OPERATIONAL TESTING}

Initial testing of the nested, fixed-depth fluidic sampling system will be performed using AEA personnel at their facility in North Carolina. This testing will be performed in accordance with the test plan that was developed by COGEMA Engineering with AEA and approved by LMHC. 
This testing will be used to demonstrate the equipments ability to meet the design and performance criteria in the Level 2 Component Specification. Additional testing of the system will be required before deployment in a DST. As detailed planning for completion of this project is performed, this section will be revised to incorporate the additional acceptance, operational, and performance testing.

\subsection{ACCEPTANCE FOR BENEFICIAL USE}

The Acceptance for Beneficial Use (ABU) process that will be used for this activity will conform with Raymond 1995a. There is no need for an ABU for work scope in FY 1998. However, to complete this project as defined in this document, an $A B U$ will be needed in FY 1999. The actual ABU checklist/forms will be added to this ETP during the FY 1999 update to the ETP. This ABU will be completed before acceptance of equipment by tank farms personnel. The completed $A B U$ form for the variable depth sampling retrieval system and on-line, real-time sample analysis system will be updated in this ETP via the ECN process.

\subsection{RISK}

There are risks associated with the performance of this activity that could impact cost and/or schedule. First of all, this is a development activity and as with any development activity there are inherent risks associated with the development process. Design descisions made early in the process may restrict the performance or limit the functionality of the equipment. In an attempt to alleviate this risk there is testing of concepts and principles which allows "decisions to proceed" to be made. However, there are other risks that are derived from external sources that can not be tested. Some of these risks are stated below. There is a risk associated with the privatization contract which will ultimately dictate acceptable sampling methods. The risk is that the contract has not been finalized and changes in the contract may impact design decisions made in early development. For instance, a design decision that was made early on in the development was to only have eight fixed sampling locations, however, the current contract states that samples should be taken from nine locations for LLW and every two feet for HLW. If these values are retained then the current design will not meet the needs of the PHMC. There is also the possibility of additional design requirements necessitated by the contract negotiations. These additional requirements would impact both the cost and deployment schedule of this sampling system. Another risk derived from external sources is the mixer pump that will be put in the feed staging tanks. There is the possibility of changes in the mixer pump design as a result of performance testing of the mixer pump. These changes may effect the expected loads that the sampler is expected to see during operations. Finally, funding is a large risk since there are up to six different funding sources for this project. Each funding source has their own priorities and it will take the cooperation of all the funding sources for this task to be successful. 
HNF-2056, REV. 0

\subsection{ORGANIZATION}

Responsibilities are assigned to various companies and organizations as identified in the following:

The LMHC Integrated Process/Product Teams (IPTs) group will provide funding and program oversight as well as technical support in the review and approval of planning and criteria documentation.

Program Manager:

Responsible Engineer:

Responsible Budget Analyst:
K. A. Gasper

J.N. Appel

P. R. Weinman

Representatives of the TFA will provide an interface to the TFA Technical Management Team to ensure that the project is implemented in a manner consistent with TFA planning and programmatic goals. Lockheed Martin Idaho Technologies Company will provide the Technical Integration Manager (TIM) who will be the point of contact for technical direction of the workscope. PNNL will provide the Technology Delivery Manager (TDM) who will support the TIM in tracking performance on key deliverables and resolution of technology deployment issues.
Responsible TIM
T. R. Thomas
Responsible TDM
B. A. Carteret

The LMHC Characterization Project Engineering (CPE) group will provide project oversight as well as technical support in the development, review, and approval of design criteria and site safety and operational documentation. CPE will also provide the cognizant engineering and design authority function.
Characterization Project Engineering
R. M. Boger (Numatec Hanford Corp.)
Design Authority
G. P. Janicek
Cognizant Manager
J. S. Schofield
Cognizant Engineer
R. G. Brown

The LMHC Data Assessment And Interpretation (DAI) group will provide support in the development and approval of criteria and test simulant documentation.

Cognizant Manager

Tank Waste Characterization
K. M. Hall

C. J. Benar 
LMHC Characterization Project Operations (CPO) will also provide safety, quality, environmental, and operations reviews of documentation as required to support this activity.
Responsible Manager
R. S. Popielarczyk
Safety Engineer
J. A. Ranshau
Quality Assurance Engineer
M. L. McElroy
Environmental Engineer
D. L. Dyekman

DESH will provide $A B$ analysis support including USQ screenings.
Responsible Manager
C. E. Leach
Responsible Engineer
T. G. Goetz

COGEMA Engineering will provide engineering services for managing the tasks associated with this project and engineering support during AEA's design and test of the prototype nested, fixed-depth fluidic sampling system. COGEMA Engineering will prepare documentation as specified in this ETP for review and issuance.
Responsible Manager
C. E. Hanson
Responsible Engineer
J. D. Criddle
Responsible Engineer
F. R. Reich
Responsible Engineer
J. L. Smalley

PNNL will perform development of test simulant criteria and provide support in the development and review of criteria and testing documents. PNNL will also provide project reporting for these tasks.

Responsible Engineer

Responsible Engineer

Responsible Engineer
M. W. Rinker

M. R. Powell

K. L. Bennett

The Fluor Daniel Hanford, Inc. (FDH) Technology Management Office is the programmatic point of contact for the TFA. FDH will provide site administration and reporting for this program.

Responsible Manager

Responsible Individual
G. T. Berlin

S. K. Foreman 
AEA Technology will perform the necessary design and proof-of-principle testing of the variable depth sample retrieval system.

\subsection{SCHEDULE}

The schedules for engineering, fabrication, and testing are dependent upon many variables. As such, this is not a "fixed schedule" estimate. COGEMA Engineering will closely manage the task and will report any potential schedule issues to the appropriate management. The schedule estimates prepared by COGEMA Engineering can be seen in Attachments A and B. Attachment $A$ is a summary schedule, while Attachment $B$ is an expanded, detailed schedule. Both schedules show all activities expected to be completed in this program. These schedules shows tasks and activities that will result in the deployment of a nested, fixed-depth fluidic sampling system with an at-tank sample analysis system in a DST. As this ETP is updated, the schedule will be updated to show the detail needed for a daily working schedule. Milestones and deliverables with completion dates for FY 1998 and the responsible organizations are shown in Table 1.

\subsection{COST}

The cost estimate is shown in the following five tables. Table 2 contains the estimated cost to perform the FY 1998 activities by each organization. Table 3 contains an estimate of the cost and proposed funding source to perform activities planned in FY 1999. Table 4 contains an estimate of the cost and proposed funding source to perform activities planned in FY 2000. Table 5 contains an estimate of the cost and proposed funding source to complete the project in FY 2001 as defined in this ETP. Table 6 shows the cost and proposed funding sources for FY 2002, which includes in-tank deployment for beneficial use with the Privatization contracts. The costs shown in these tables are dependent upon many variables and, as such, are not "fixed price" estimates. COGEMA Engineering will manage the task closely and report any cost issues to the appropriate management. 
HNF-2056, REV. 0

Table 1. Milestones and Deliverables for FY 1998

\begin{tabular}{|l|l|l|}
\hline \multicolumn{1}{|c|}{ Description } & \multicolumn{1}{|c|}{ Due Date } & \multicolumn{1}{c|}{ Responsible Organization } \\
\hline Prepare TTP & $03 / 27 / 98$ & COGEMA \\
\hline 98-1 Select sampling concept( ${ }^{(1)}$ & $02 / 1 / 98$ & LMHC \\
\hline Issue draft ETP for review and comment & $03 / 31 / 98$ & COGEMA \\
\hline 98-2 Identify Preliminary set of analytes ${ }^{(1)}$ & $04 / 15 / 98$ & PNNL \\
\hline 98-6 Issue Test Simulant Specification for review ${ }^{(1)}$ & $04 / 28 / 98$ & PNNL \\
\hline Deployment Strategy and Plan document & $06 / 30 / 98$ & LMHC \\
\hline Complete an interim design review of AEA design & $06 / 30 / 98$ & LMHC \\
\hline 98-3 Review preliminary design for analysis system ${ }^{(1)}$ & $06 / 30 / 98$ & LMHC \\
\hline 98-4 Issue Test Plan Guidance Document to AEA ${ }^{(1)}$ & $07 / 15 / 98$ & LMHC \\
\hline Issue ETP as PHMC Team document & $08 / 30 / 98$ & COGEMA \\
\hline $\begin{array}{l}\text { Complete Demonstration of Nested, Fixed-depth } \\
\text { Fluidic Sampling Prototype }\end{array}$ & $09 / 15 / 98$ & AEA \\
\hline 98-5 Issue Draft Level 2 Component Specification ${ }^{(1)}$ & $09 / 30 / 98$ & COGEMA \\
\hline Issue results of design review & $09 / 30 / 98$ & COGEMA \\
\hline FY 1998 TTP Summary Report & $10 / 30 / 98$ & LMHC/COGEMA \\
\hline
\end{tabular}

Note: (1) Technical Task Proposal (TTP) milestone. 
Table 2. Estimated Cost Distribution of FY 1998 Fund

\begin{tabular}{|c|c|c|c|}
\hline \multirow[b]{2}{*}{ Task } & \multicolumn{3}{|c|}{ Funding Source $(\$ 000)^{(2)}$} \\
\hline & $\begin{array}{l}\text { EM-30, } \\
\text { TWRS Tank } \\
\text { Waste } \\
\text { Retrieval }\end{array}$ & EM-50-TFA & $\begin{array}{l}\text { EM-50 } \\
\text { Robotics } \\
\text { Cross-Cut } \\
\text { Program }\end{array}$ \\
\hline A. Program Management & 10 & 52 & \\
\hline B. Project Planning - Deployment Strategy and Plan: & & 16 & \\
\hline C. Project Planning - Engineering Task Plan (ETP): & & 19 & \\
\hline D. Test Simulant Development: & & 51 & \\
\hline E. Level 2 Component Specification: & & 55 & \\
\hline F. Test Plan: & & 42 & \\
\hline G. Sampler Hardware Development: & & 35 & \\
\hline $\begin{array}{l}\text { Level } 2 \text { Component Specification - At-Tank Analysis } \\
\text { System: } \\
\text { H - Design Review - Nested, fixed-depth sampling } \\
\text { system and at-tank sample analysis concepts }\end{array}$ & & 6 & \\
\hline $\begin{array}{c}\text { At-Tank Analysis System Concept Development } \\
\text { I - Concept Identification }\end{array}$ & & & $50 ?$ \\
\hline $\begin{array}{l}\text { Level } 2 \text { Component Specification - At-Tank Analysis } \\
\text { System: } \\
\qquad \text { J - Preliminary Level } 2 \text { Component Specification: }\end{array}$ & & & $50 ?$ \\
\hline TOTAL: & 10 & $276^{(2)}$ & 100 \\
\hline
\end{tabular}

Notes:

(1) PNNL Technical Task Proposal (TTP) funding from Robotics Cross-Cut Program that supports this work (TTP RL37C131)

(2) G\&A/CSP not included. 
Table 3. Estimated Costs and Proposed Funding Sources for FY 1999

\begin{tabular}{|l|c|c|c|}
\hline \multicolumn{1}{|c|}{ Task } & \multicolumn{2}{c|}{ Proposed Funding Source (\$000) } \\
\cline { 2 - 4 } & $\begin{array}{c}\text { EM-30 - } \\
\text { TWRS }\end{array}$ & EM-50 - TFA & $\begin{array}{c}\text { EM-50 - } \\
\text { Other }\end{array}$ \\
\hline Program Management - Technical Integration and Reporting: & 100 & 50 & 50 \\
\hline $\begin{array}{l}\text { Engineering Task Plan and Deployment Strategy and Plan } \\
\text { Documents Revision }\end{array}$ & & 20 & \\
\hline Nested, Fixed-depth Sampling System: & & & \\
\hline $\begin{array}{l}\text { Level 2 Component Specification - Update Specification/ } \\
\text { Criteria for Nested, Fixed-depth Sampling and at-Tank } \\
\text { Analysis Systems }\end{array}$ & & 30 & \\
\hline $\begin{array}{l}\text { Design/Fabrication/Acceptance - Conceptual, Definitive } \\
\text { Design, Procurement,/Fabrication }\end{array}$ & & 30 & 650 \\
\hline $\begin{array}{l}\text { Tank Interface System Hardware - Conceptual, Definitive } \\
\text { Design, Procurement,/Fabrication }\end{array}$ & & & \\
\hline $\begin{array}{l}\text { Nested, Fixed-depth Sampling.System Cold Testing - Select } \\
\text { Site and initiate preparations for a cold testing and } \\
\text { demonstration }\end{array}$ & 10 & & \\
\hline $\begin{array}{l}\text { In-tank Deployment Documentation -Complete Nested, } \\
\text { Fixed-depth Sampling System Hazards Assessment }\end{array}$ & & & \\
\hline At-Tank Analysis System & & & \\
\hline $\begin{array}{l}\text { Concept Development and Testing -Concept Development } \\
\text { and Testing }\end{array}$ & & & \\
\hline Definitive Design & & & \\
\hline & & & \\
\hline
\end{tabular}


Table 4. Estimated Costs and Proposed Funding Sources for FY 2000

\begin{tabular}{|l|c|c|c|}
\hline \multicolumn{1}{|c|}{ Task } & \multicolumn{2}{c|}{ Proposed Funding Source (\$000) } \\
\cline { 2 - 4 } & $\begin{array}{c}\text { EM-30 - } \\
\text { TWRS }\end{array}$ & EM-50 - TFA & $\begin{array}{c}\text { EM-50 - } \\
\text { Other }\end{array}$ \\
\hline Program Management - Technical Integration and Reporting: & 100 & 50 & 50 \\
\hline $\begin{array}{l}\text { Engineering Task Plan and Deployment Strategy and Plan } \\
\text { Revisions }\end{array}$ & & 20 & \\
\hline Nested, Fixed-depth Sampling System: & & & \\
\hline $\begin{array}{l}\text { Fabrication and Acceptance - Hardware Acceptance and Ck } \\
\text { out }\end{array}$ & & & 5 \\
\hline Tank Interface System Hardware Acceptance and Checkout & & & 5 \\
\hline $\begin{array}{l}\text { System Cold Testing - Cold Test Facility Preparation, Cold } \\
\text { Testing and Lessons-Learned Modifications }\end{array}$ & & & 190 \\
\hline Acceptance Testing & 10 & & 200 \\
\hline Operational Testing and Operator Training & 10 & & \\
\hline In-tank Deployment Documentation: & & & \\
\hline In-tank Hot Installation - Hot Installation Plan and Schedule & 10 & & \\
\hline $\begin{array}{l}\text { Readiness Assessment Requirements Defined - Tank } \\
\text { Installation/Operation }\end{array}$ & & & \\
\hline At-tank Analysis System & & & \\
\hline Hardware Procurement, Fabrication, and Acceptance & & & \\
\hline System Cold Testing & & & \\
\hline & & & \\
\hline
\end{tabular}


Table 5. Estimated Costs and Proposed Funding Sources for FY 2001

\begin{tabular}{|l|c|c|c|}
\hline \multirow{2}{*}{\multicolumn{1}{|c|}{ Task }} & \multicolumn{2}{c|}{ Proposed Funding Source (\$000) } \\
\cline { 2 - 4 } & $\begin{array}{c}\text { EM-30 - } \\
\text { TWRS }\end{array}$ & EM-50 - TFA & $\begin{array}{c}\text { EM-50 - } \\
\text { Other }\end{array}$ \\
\hline Program Management - Technical Integration and Reporting: & 100 & & 100 \\
\hline $\begin{array}{l}\text { Engineering Task Plan and Deployment Strategy and Plan } \\
\text { Revisions }\end{array}$ & & 10 & \\
\hline Nested, Fixed-depth Sampling System: & & & \\
\hline Readiness Review - In-tank Installation and Operation & 10 & & \\
\hline $\begin{array}{l}\text { In-tank Hot Installation and Operation - In-tank installation } \\
\text { and functional checkout }\end{array}$ & 20 & & \\
\hline Hot Testing and Demonstration - Hot Test Plan & 30 & & 125 \\
\hline $\begin{array}{l}\text { Hot Testing and Demonstration - Hot testing and } \\
\text { Demonstration }\end{array}$ & & & \\
\hline $\begin{array}{l}\text { System Hot Testing and Demonstration - Readiness Checklist } \\
\text { for Continued Operation }\end{array}$ & 10 & & \\
\hline At-tank Analysis System & 15 & & \\
\hline Prepare Acceptance Test Plan and Operational Test Plan & & & \\
\hline System Deployment Documentation & & & \\
\hline
\end{tabular}


Table 6. Estimated Costs and Proposed Funding Sources for FY 2002

\begin{tabular}{|l|c|c|c|}
\hline \multirow{2}{*}{ Task } & \multicolumn{2}{c|}{ Proposed Funding Source (\$000) } \\
\cline { 2 - 4 } & $\begin{array}{c}\text { EM-30 - } \\
\text { TWRS }\end{array}$ & EM-50 - TFA & $\begin{array}{c}\text { EM-50 - } \\
\text { Other }\end{array}$ \\
\hline Program Management - Technical Integration and Reporting: & 100 & & 50 \\
\hline $\begin{array}{l}\text { Engineering Task Plan and Deployment Strategy and Plan } \\
\text { Revisions }\end{array}$ & & 10 & \\
\hline Nested, Fixed-depth Sampling System: & & & \\
\hline $\begin{array}{l}\text { In-tank Hot Testing and Demonstration - Integration with } \\
\text { At-tank analysis system }\end{array}$ & & & \\
\hline At-tank Analysis System & & & \\
\hline Acceptance Testing & & & 235 \\
\hline Operational Testing and Operator Training & 210 & & \\
\hline Readiness Assessment - At-tank Installation and Operation & 100 & & \\
\hline Hot Installation & 85 & & \\
\hline $\begin{array}{l}\text { System Hot Testing and Demonstration - Hot Testing Plan } \\
\text { and Initiation of Testing }\end{array}$ & 35 & & 335 \\
\hline
\end{tabular}


Table 7. Estimated Costs and Proposed Funding Sources for FY 2003

\begin{tabular}{|l|c|c|c|}
\hline \multirow{2}{*}{ Task } & \multicolumn{3}{c|}{ Proposed Funding Source (\$000) } \\
\cline { 2 - 4 } & $\begin{array}{c}\text { EM-30 - } \\
\text { TWRS }\end{array}$ & $\begin{array}{c}\text { EM-50 - } \\
\text { TFA }\end{array}$ & $\begin{array}{c}\text { EM-50 - } \\
\text { Other }\end{array}$ \\
\hline $\begin{array}{l}\text { Program Management - Technical Integration and } \\
\text { Reporting: }\end{array}$ & 50 & & 25 \\
\hline At-tank Analysis System & & & 150 \\
\hline Hot Testing and Hot Demonstration & & & \\
\hline $\begin{array}{l}\text { System Hot Testing and Demonstration - Readiness Checklist } \\
\text { for Continued Operation }\end{array}$ & 10 & & 175 \\
\hline \multicolumn{1}{|c|}{ TOTAL: } & 60 & & \\
\hline
\end{tabular}




\subsection{CONFIGURATION MANAGEMENT}

The portion of the task to be completed in FY 1998 is being performed per the development control process (HNF 1997g); therefore, released engineering drawings are not required of the retrieval system before testing for proof-of-principle. Drawings, sketches, and specifications will be developed by AEA for LMHC approval before fabrication of the prototype. AEA will create a master copy of the approved design media. Any modifications needed to the design media after the initial approval of LMHC will be done per the following "redline" process. AEA will redline a copy of the design media with the proposed change and submit that change to the designated LMHC design agent for review and approval. The redline change is approved after representatives from both AEA and LMHC have signed the redline change. Once approval has been obtained for the change, AEA will update the master copy of the design media with the redline. The purpose for following this procedure is to maintain configuration control of the tested equipment, thereby maintaining the facility use potential of the equipment. Any changes made to the equipment must be approved before initiating proof-of-principle testing.

In FY 1999, the development control process will transition to configuration control before equipment turnover to operations. This means that design media will be created in accordance with Hanford Policy and Procedures for development of drawings (WHC 1996b, HNF 1997i), and Vendor Information Files (HNF 1997j). After configuration control has been established to the requirements of HNF 1997k, changes in the configuration will be controlled through the Engineering Change Notice (ECN) process (WHC 1996b, HNF 1997d). Any new drawings associated with this task will be categorized as essential, support, or information, as required by HNF 1997i. Approved design media must be created before installation of the components into a Hanford waste tank.

\subsection{QUALITY ASSURANCE}

All documentation (ECNs, etc.) associated with this task, which will be released as a PHMC team document, will be assigned approval designators by the responsible engineer, with concurrence from the cognizant manager. The approval designator will be determined from Table 1 of HNF 19971. Those documents given an approval designator "Q" will by reviewed and approved by Quality Assurance per WHC 1991. 


\subsection{SAFETY}

\subsection{NUCLEAR SAFETY AND LICENSING}

A preliminary hazards assessment of the conceptual design for the sample retrieval system and the tank interface systems will be performed. This assessment will include shipping of the sample to the laboratory for analysis. The preliminary hazards assessment will be used to perform a USQ screening/determination against the current tank farm AB (LMHC 1997a, LMHC 1997b). The outcome of this USQ will determine the work necessary to encompass this activity in the tank farm AB. This work will be as performed per HNF $1997 \mathrm{~m}$ and HNF 1997n.

\subsection{SAFETY}

All documentation (ECNs, etc.) associated with this task will be assigned approval designators by the responsible engineer with concurrence from the cognizant manager. The approval designator will be determined from Table 1 of HNF 19971. Those documents given an approval designator " $S$ " will be reviewed and approved by Safety.

\subsection{ENVIRONMENTAL}

All documentation (ECNs, etc.) associated with this task will be assigned approval designators by the responsible engineer with concurrence from the cognizant manager. The approval designator will be determined from Table 1 of HNF 19971. Those documents given an approval designator " $E$ " will be reviewed and approved by Environmental Compliance.

\subsection{SYSTEM ENGINEERING}

This task plan defines the necessary work required to achieve the goal of proof-of-principle testing for a variable depth sample retrieval system in FY 1998 and eventual deployment of the system in a DST. This activity is not currently covered under the Work Breakdown Structure (WBS). When the WBS was planned, the assumption was that the method used to retrieve samples from the PHMC team feed tanks would be grab sampling. If proof-of-principle testing for this system is successful, it is planned to initiate a change request to the WBS in early FY 1999 for the purpose of including the scope of work to deploy this system in a DST with the expectation that the nested, fixed-depth fluidic sampling system would eventually replace the currently planned grab sampling method of sample retrieval. 


\subsection{CLOSEOUT COSTS}

Should this project be prematurely terminated in FY 1998, funds would be required to document the work status of the incomplete tasks, collect and sort the documentation, and file incomplete work in a retrievable format. It is estimated that COGEMA Engineering would require between $\$ 10,000$ and $\$ 15,000$ to perform this closeout which would be dependent on the progress made toward project completion before termination notice. This section will be updated for follow-on years as detailed planning is performed and this ETP is updated. 


\subsection{REFERENCES}

Boger, R. M., 1997, Engineering Task Plan, Characterization Project Desk Instruction DI-CP-002-00, Revision 1, Lockheed Martin Hanford Corporation, Richland, Washington.

DOE, 1997a, DE-AC06-RL13308, BNFL Inc. Privatization Contract, U.S. Department of Energy, Richland Operations Office, Richland, Washington.

DOE, 1997b, DE-AC06-RL13309, Lockheed Martin Advanced Environmental Systems Privatization Contract, U.S. Department of Energy, Richland Operations Office, Richland, Washington.

HNF, 1997a, HNF-PRO-448, Rev. 0, Project Hanford Policy and Procedure System Interim Design Authority/Design Agent Engineering Process Requirements, Fluor Daniel Hanford, Inc., Richland, Washington.

HNF, 1997b, HNF-PRO-244, Rev. 0, Project Hanford Policy and Procedure System Engineering Data Submittal Requirements, Fluor Daniel Hanford, Inc., Richland, Washington.

HNF, 1997c, HNF-PRO-317, Rev. 0, Project Hanford Policy and Procedure System Engineering Release and Approval Requirements, Fluor Daniel Hanford, Inc., Richland, Washington.

HNF, 1997d, HNF-PRO-440, Rev. 1, Project Hanford Policy and Procedure System Engineering Document Change Control Requirements, Fluor Daniel Hanford, Inc., Richland, Washington.

HNF, 1997e, HNF-PRO-561, Rev. 0, Project Hanford Policy and Procedure System Functional Design Criteria, Fluor Daniel Hanford, Inc., Richland, Washington.

HNF, 1997f, HNF-PRO-446, Rev. 0, Project Hanford Policy and Procedure System Testing Practices Requirements, Fluor Daniel Hanford, Inc., Richland, Washington.

HNF, 1997g, HNF-PRO-442, Rev. 0, Project Hanford Policy and Procedure System Development Control Requirements, Fluor Daniel Hanford, Inc., Richland, Washington.

HNF, 1997h, HNF-PRO-445, Rev. 0, Project Hanford Policy and Procedure System Design Verification Requirements, Fluor Daniel Hanford, Inc., Richland, Washington. 
HNF, 1997i, HNF-PRO-242, Rev. 1, Project Hanford Policy and Procedure System Engineering Drawing Requirements, Fluor Daniel Hanford, Inc., Richland, Washington.

HNF, 1997j, HNF-PRO-444, Rev. 1, Project Hanford Policy and Procedure System Vendor Information Requirements, Fluor Daniel Hanford, Inc., Richland, Washington.

HNF, 1997k, HNF-PRO-227, Rev. 0, Project Hanford Policy and Procedure System Engineering Document Identification, Fluor Daniel Hanford, Inc., Richland, Washington.

HNF, 19971, HNF-PRO-233, Rev. 0, Project Hanford Policy and Procedure System Review and Approval of Documents, Fluor Daniel Hanford, Inc., Richland, Washington.

HNF, 1997m, HNF-PRO-700, Rev 1, Project Hanford Policy and Procedure System Safety Analysis Technical Safety Requirements, Fluor Daniel Hanford, Inc., Richland, Washington.

HNF, 1997n, HNF-PRO-704, Rev. 0, Project Hanford Policy and Procedure System Hazard and Accident Analysis Procedure, Fluor Daniel Hanford, Inc., Richland, Washington.

LMHC, 1997a, HNF-SD-WM-BIO-001, Latest Revision, Tank Waste Remediation System Basis for Interim Operation, Lockheed Martin Hanford Corporation, Richland, Washington.

LMHC, 1997b, HNF-SD-WM-TSR-006, Latest Revision, Tank Waste Remediation System Technical Safety Requirements, Lockheed Martin Hanford Corporation, Richland, Washington.

Raymond, R. E., 1995, "Acceptance for Beneficial Use (ABU), "Internal Letter 75200-95-013, Attachment 4, DI-75200-004-00, Revision 0, Westinghouse Hanford Company, Richland, Washington.

WHC, 1991, WHC-CM-4-2, Quality Assurance Manual, Westinghouse Hanford Company, Richland, Washington.

WHC, 1996a, WHC-IP-0842, TWRS Administration, Volume IV, Section 3.1 1, "Replacement Item Evaluation, Commercial Grade Item Dedication and Upgrade," Westinghouse Hanford Company, Richland, Washington.

WHC, 1996b, WHC-IP-0842, TWRS Administration, Volume IV, Section 3.5, "Engineering Documents," Westinghouse Hanford Company, Richland, Washington. 
HNF-2056, REV. 0

ATTACHMENT A

SUMMARY SCHEDULE OF ACTIVITIES 


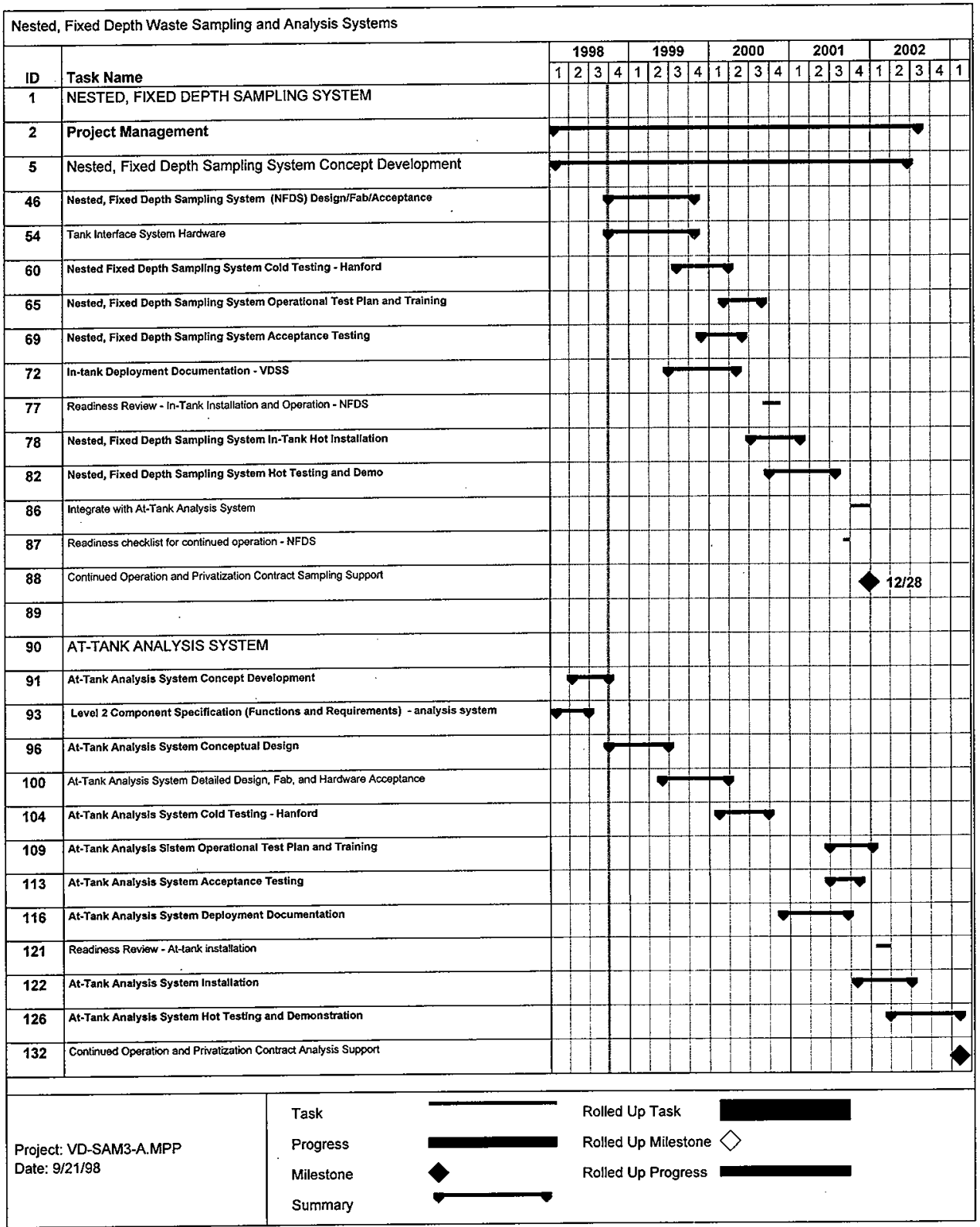




\section{ATTACHMENT B}

\section{DETAILED SCHEDULE OF ACTIVITIES}




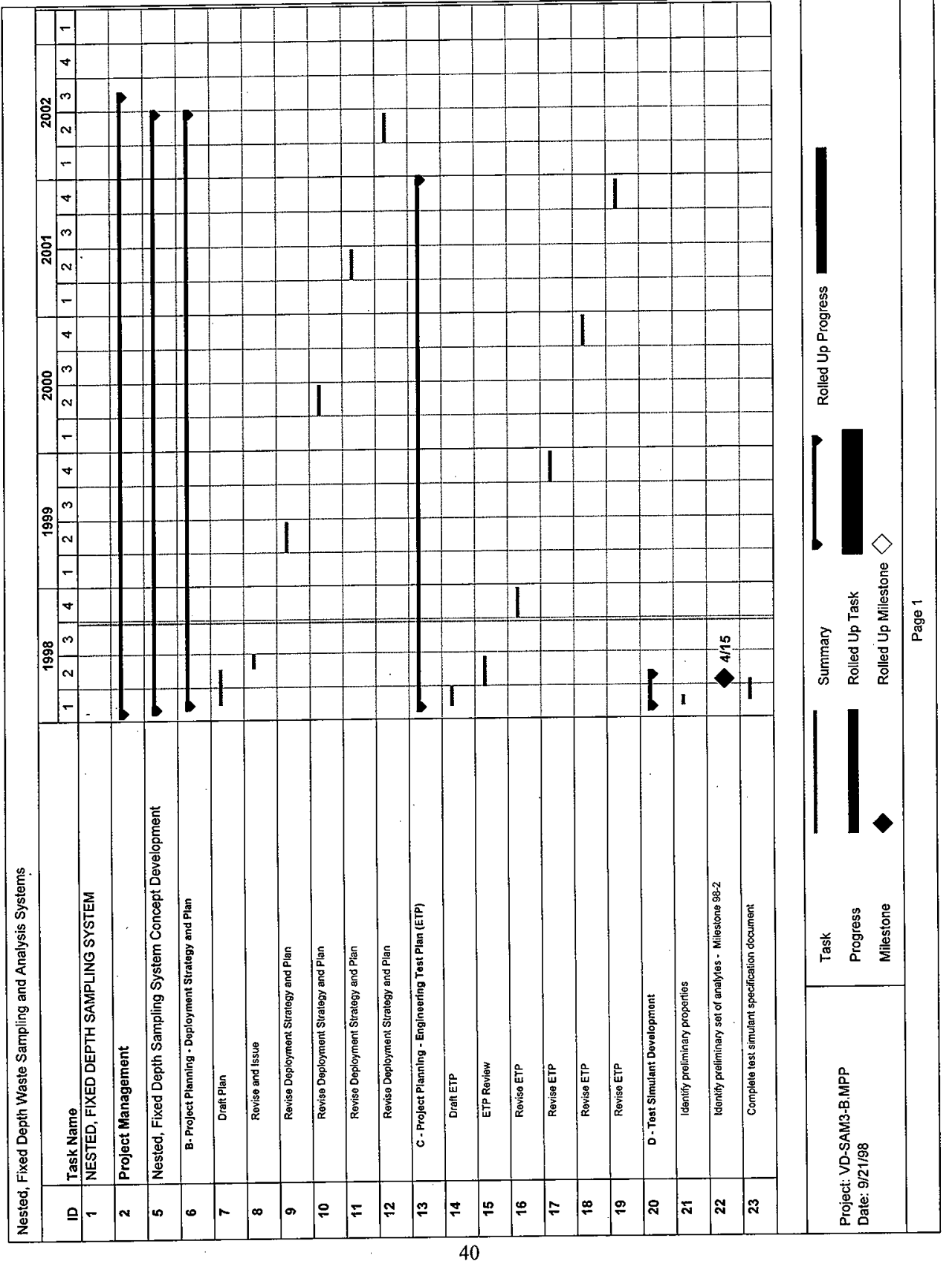




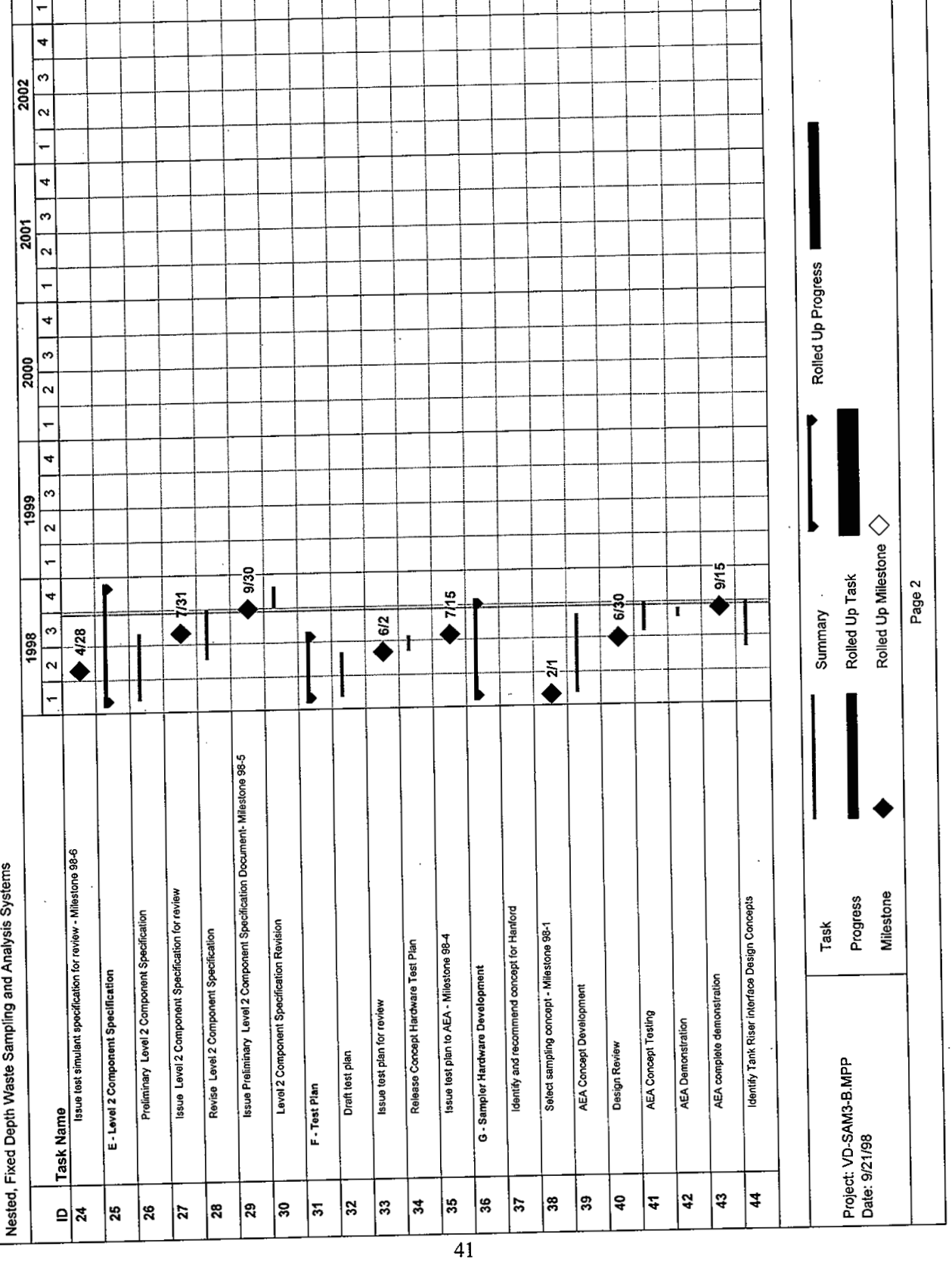


HNF-2056, REV. 0

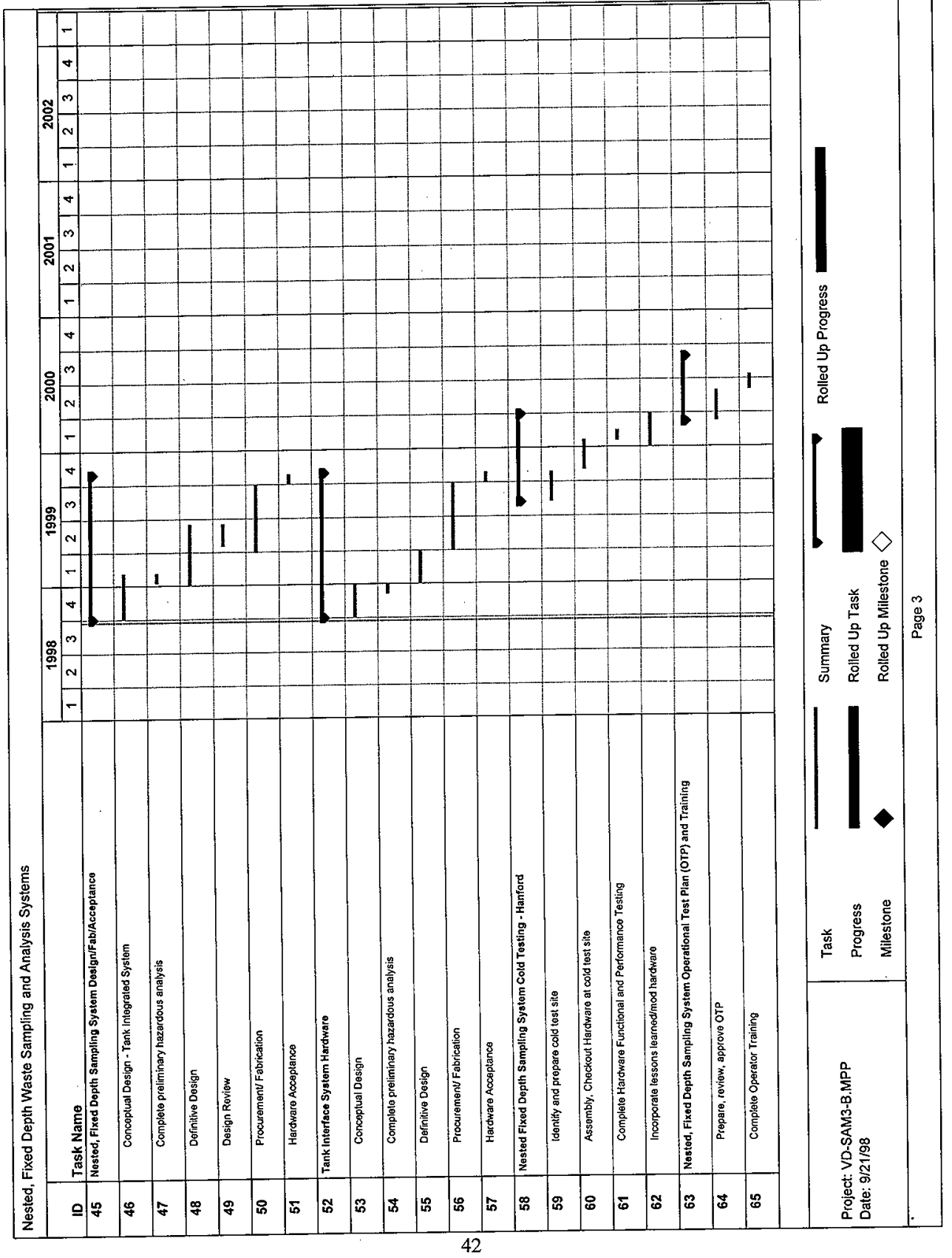




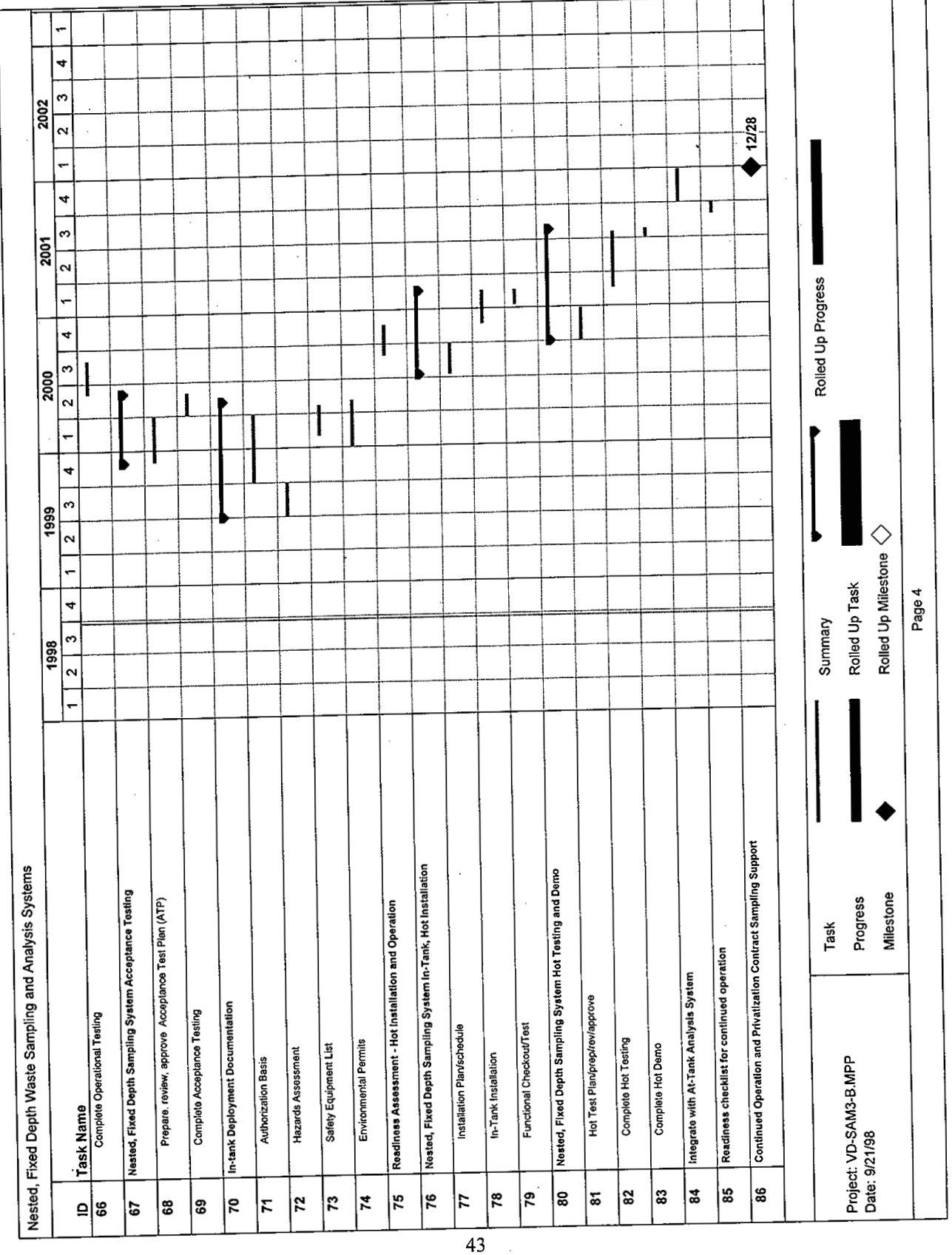


HNF-2056, REV. 0

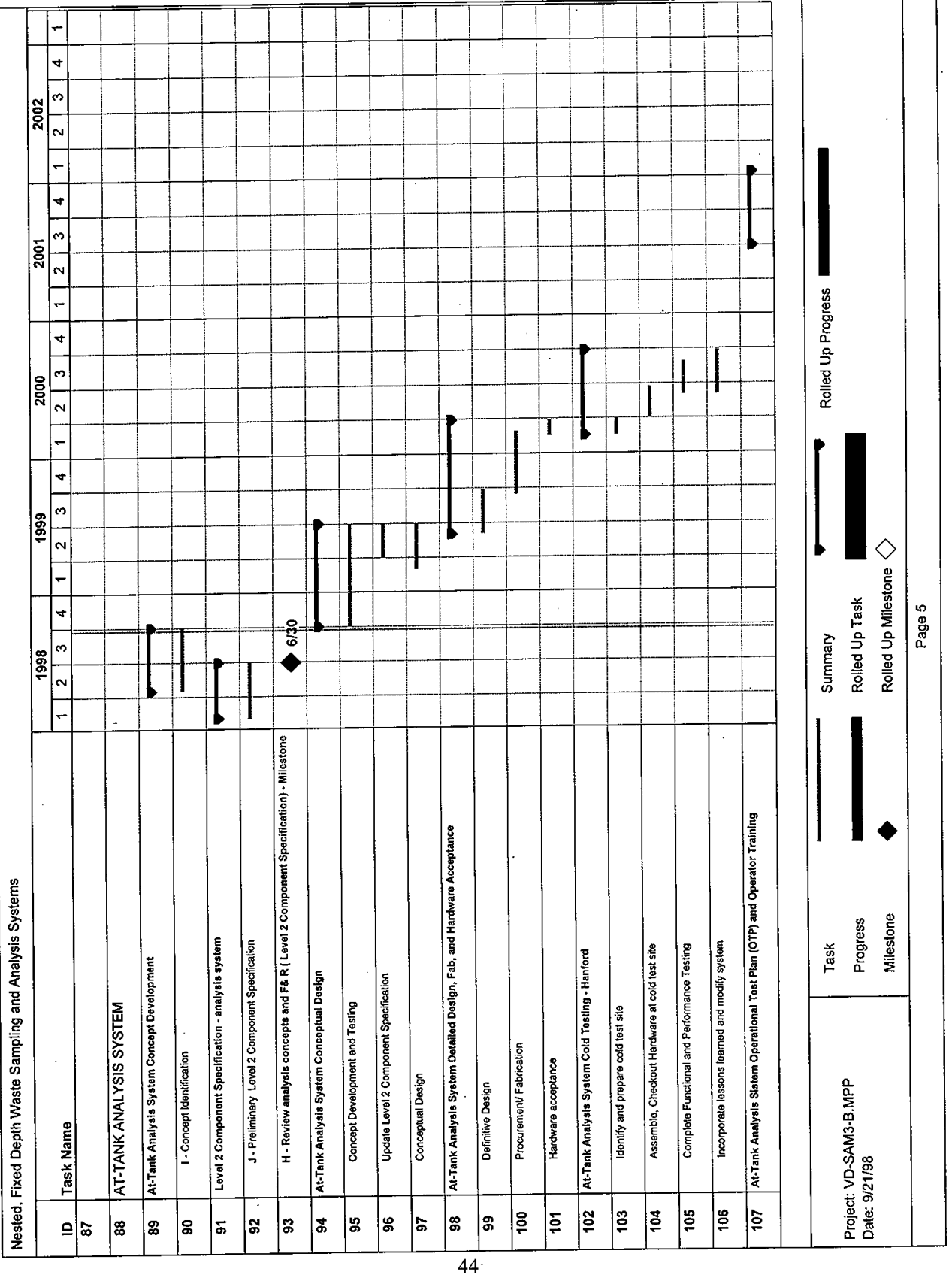


HNF-2056, REV. 0

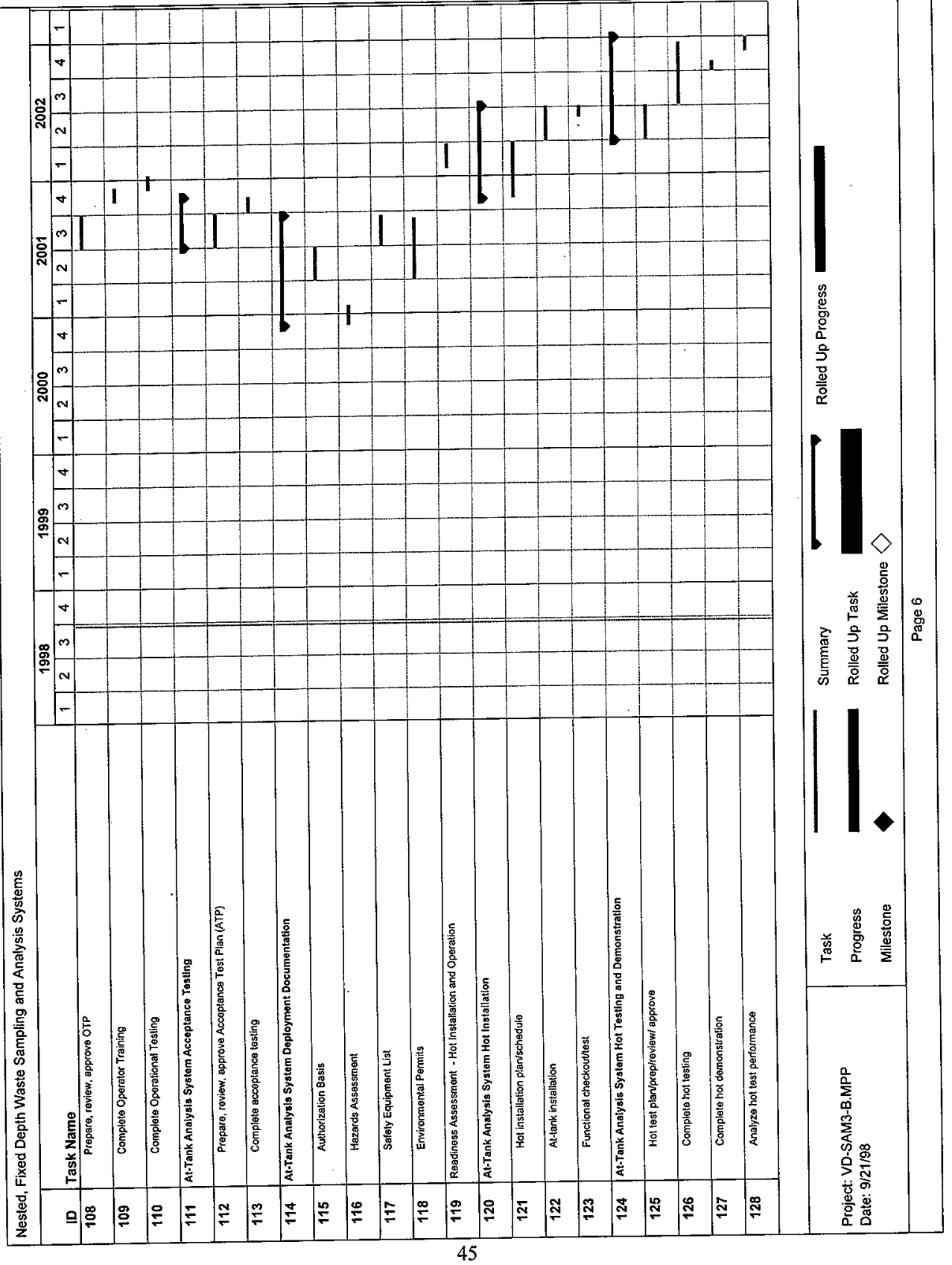




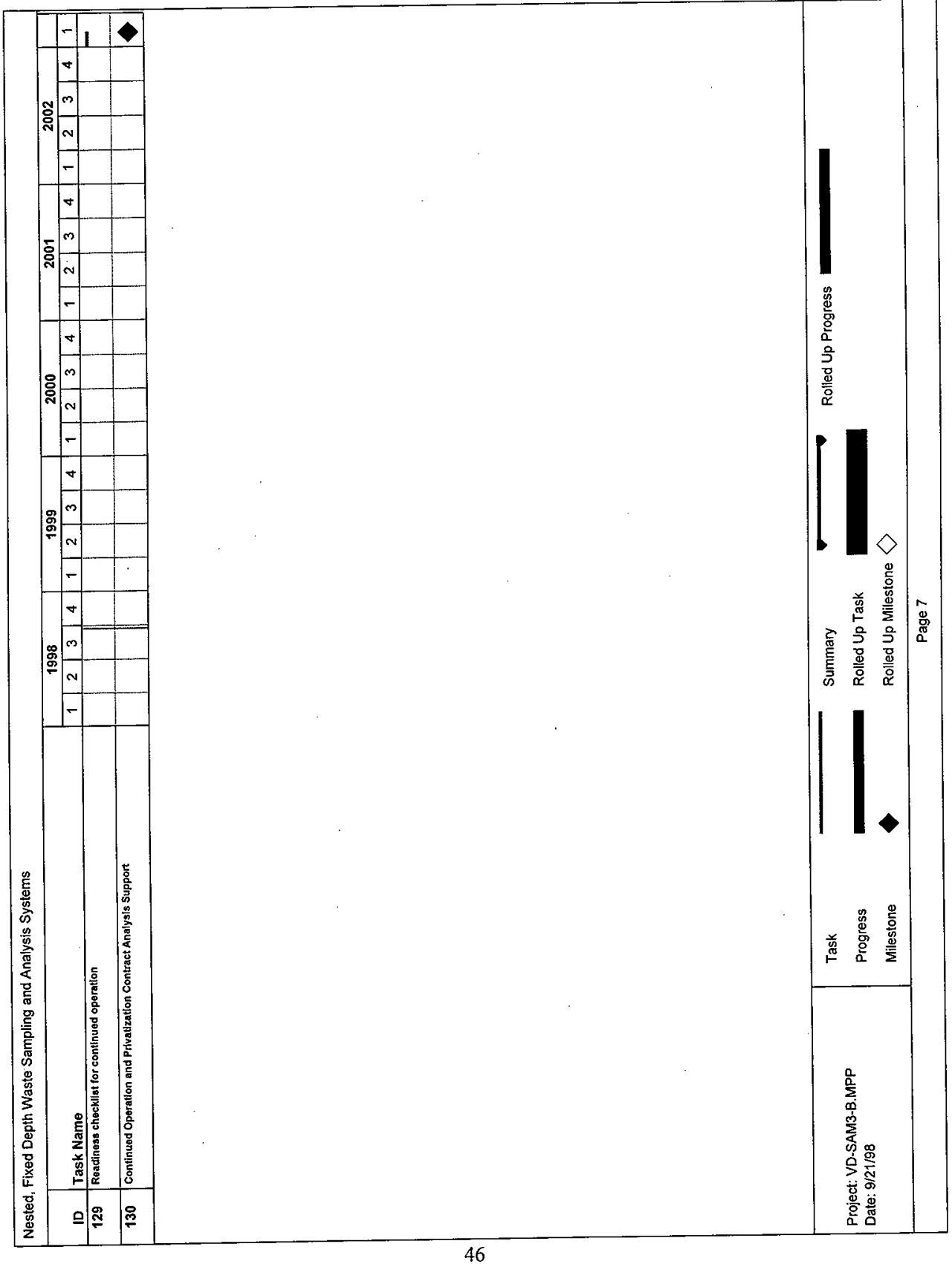

